\title{
Optimization of Production Conditions for Bioactive Polysaccharides from Fomes fomentarius and Investigation of Antibacterial and Antitumor Activities
}

\author{
Hale Alvandi ${ }^{1}$, Ashrafalsadat Hatamian-Zarmi ${ }^{1 *}$, \\ Bahman Ebrahimi Hosseinzadeh ${ }^{1}$, Zahra Beagom Mokhtari-Hosseini ${ }^{2}$,
}

1. Department of Life Science Engineering, Faculty of New Sciences and Technologies, University of Tehran, Tehran, Iran

2. Department of Chemical Engineering, Faculty of Petroleum and Petrochemical Engineering, Hakim Sabzevari University, Sabzevar, Iran

\section{$\underline{10.30699 / i j m m .14 .5 .596}$}

\section{ABSTRACT}

Background: One of the medicinal fungi that has been used in traditional medicine for a long time is the Basidiomycete fungus Fomes fomentarius, which is widely distributed in Iran. Polysaccharides as one of the metabolites of this fungus have anti-inflammatory, anti-diabetic, antibacterial, antioxidant, and anti-cancer properties.

Materials \& Methods: Optimization of independent variables of $\mathrm{MgSO}_{4} .7 \mathrm{H}_{2} \mathrm{O}$ concentration, initial pH, yeast extract, and inoculum percentage to increase biomass and polysaccharide production of $F$. fomentarius was investigated using the Taguchi method. Then, the biological properties of the produced polysaccharide including antibacterial activity was investigated by bacterial colony counting method, antioxidant activity using DPPH free radical, and antiproliferative effect on 5 cancer cell lines MKN-45, AGS, A549, KYSE-30 and 5637 using MTS test.

Results: The concentration of $\mathrm{MgSO}_{4} .7 \mathrm{H}_{2} \mathrm{O}$ and initial $\mathrm{pH}$ had a significant effect $(P<0.05)$ on the production of $F$. fomentarius polysaccharide and in optimal conditions polysaccharide production reaches $5.410 \mathrm{~g} / \mathrm{L}$. The polysaccharide of this fungus inhibits the growth of Staphylococcus aureus and Escherichia coli bacteria by $50 \%$ and $25 \%$, respectively. The antioxidant activity of this polysaccharide in the DPPH test is $16.11 \%$. The antiproliferative effect of this polysaccharide on cancer cells is different (KYSE$30>$ A549 $\geq 5637>$ AGS> MKN-45). This effect increases with increasing concentration. In KYSE-30 cell line treatment with 200 $\mathrm{g} / \mathrm{mL}$ polysaccharide, cell viability reaches $40 \%$ after 72 hours.

Conclusion: Optimizing the culture medium of the medicinal fungus Fomes fomentarius increases the production of polysaccharides up to $5.410 \mathrm{~g} / \mathrm{L}$. Optimization increases the biological activity of polysaccharides. Antibacterial activity against Staphylococcus aureus and Escherichia coli is $50 \%$ and $25 \%$, respectively. The antioxidant activity of polysaccharides is $16.11 \%$ and the viability of KYSE-30 cancer cells reaches $40 \%$ after 72 hours.

Keywords: Fomes fomentarius, Optimization, Taguchi, Antibacterial, Antioxidant, Anticancer

Received: 2020/08/27; Accepted: 2020/10/05; Published Online: 2020/10/20

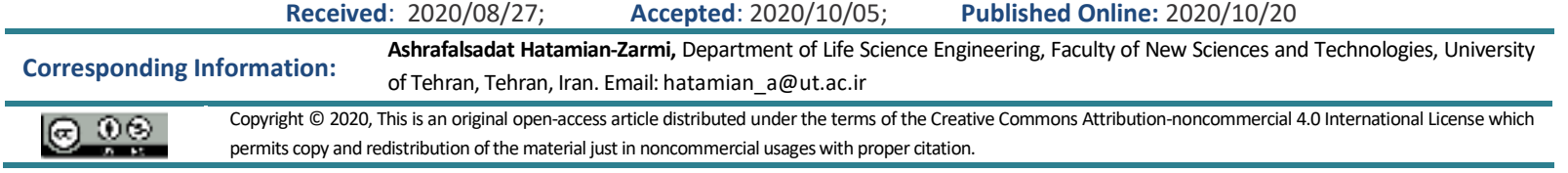

Use your device to scan and read the article online

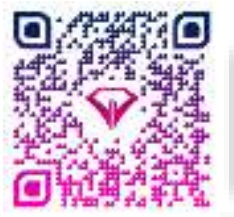

Alvandi H, Hatamian-Zarmi A, Ebrahimi Hosseinzadeh B, Mokhtari-Hosseini Z. Optimization of Production Conditions for Bioactive Polysaccharides from Fomes fomentarius and Investigation of Antibacterial and Antitumor Activities. Iran J Med Microbiol. 2020; 14 (6) :596-611

\section{Download citation: BibTeX | RIS | EndNote | Medlars | ProCite | Reference Manager | RefWorks}

$$
\text { Send citation to: } \& \underline{\text { Mendeley }} \mathbf{Z} \text { Zotero } 1 \text { RefWorks }
$$

\section{Introduction}

The history of using medicinal fungi in East Asian countries dates back to thousands of years ago. Many of these fungi are still used to treat diseases (1). The medicinal fungi properties include stimulating the proliferation of lymphocytes, reducing the proliferation of cancer cells, and anti-inflammation. The increasing importance of medicinal 
fungi and their metabolites in the treatment of various diseases, the appropriate biodiversity of medicinal fungi in Iran, and the economic value of metabolites derived from these fungi indicate the need to pay attention to this branch of biological sciences (2). Among the medicinal fungi, Basidiomycete Fomes fomentarius has long been used in the treatment of gastrointestinal diseases, liver cirrhosis, and various cancers. The distribution of this fungus is widespread in Iran and its presence has been reported in Mazandaran, Golestan, Gilan, Isfahan, Tehran, Kurdistan, Kermanshah, Khorasan and Azerbaijan provinces $(2,3)$. This fungus has important properties in various aspects. This species is considered as one of the important causes of white heart rot on forest trees. Its extract has antioxidant and anti-cancer properties. F. fomentarius is also considered for the production of the laccase enzyme and use in processes such as decolorization and biodegradation (3-5). One of the bioactive compounds of this fungus is polysaccharides that have anti-cancer, anti-inflammatory, anti-diabetic, and immune-enhancing activities. $F$. fomentarius $\beta$-glucan polysaccharide prevents tumor angiogenesis and metastasis $(6,7)$. The anti-proliferative effect of this polysaccharide has been observed on SGC7901, A549, MCF7, and MKN-45 cancer cell lines $(4,5,8)$. Studies show that the polysaccharides of $F$. fomentarius also have antibacterial and antiviral activity $(9,10)$. Chen et al. (2008), examined the biomass and polysaccharide production of $F$. fomentarius in submerging culture conditions. A temperature of $25^{\circ} \mathrm{C}$ and an initial $\mathrm{pH}$ in the range of 5-6 are suitable for the growth of this fungus. Also, using glucose as carbon source, yeast extract as a nitrogen source, $\mathrm{CaCl}_{2}$ and $\mathrm{MgSO}_{4} .7 \mathrm{H}_{2} \mathrm{O}$ improves mycelial growth and increases polysaccharide production (11). Cultures of $F$. fomentarius in stirred bioreactor and solid bed bioreactor have also been studied $(4,12)$. Many studies have been done on optimizing the culture medium for the growth of other fungi and their metabolite production. One of these statistical methods is the Taguchi array design, which allows the study and optimization of several variables simultaneously (13). Therefore, in this study, the production of biomass and polysaccharide of the Iranian medicinal fungus $F$. fomentarius, which has been isolated from the forests of Mazandaran, was investigated. Also, the composition of the culture medium of this fungus was optimized to increase the production of biomass and polysaccharide by the Taguchi method. Then the biological activities of polysaccharides including antibacterial, antioxidant, and cytotoxicity were investigated.

\section{Materials and Methods}

\section{Collection of Mushroom Samples}

The $F$. fomentarius was isolated from Mazandaran forests in 2017 with the cooperation of Sari Agricultural Sciences and Natural Resources University. In each case, the fungal specimen was harvested in a healthy, complete and appropriate manner based on the color, shape, size and surface decoration of the cap, base, blades and many other characteristics. After morphological confirmation by mycologists, it is kept at $4^{\circ} \mathrm{C}$.

\section{Cultivation of $F$. fomentarius and Polysaccharides Extraction}

The $F$. fomentarius mycelium was cultured in potato dextrose agar (PDA) (manufactured by Merck, Germany) in a petri dish and incubated for 5 days at $28^{\circ} \mathrm{C}$ (BINDER, USA). For seed culture, $10 \mathrm{~mm}^{2}$ pieces of fungus grown in PDA medium were transferred to 100 $\mathrm{mL}$ of Potato dextrose broth (PDB) medium (manufactured by Merck, Germany) for 7 days at $28^{\circ} \mathrm{C}$ and $150 \mathrm{rpm}$ in shaker incubator (JAL TAJHIZ, Iran). Suitable culture medium of this fungus includes glucose $(5 \%)$, peptone $(0.2 \%)$, malt extract $(1 \%)$, yeast extract $(0.2 \%), \mathrm{MgSO}_{4} .7 \mathrm{H}_{2} \mathrm{O}(0.25 \%)$ and $\mathrm{KH}_{2} \mathrm{PO}_{4}(0.5 \%)$. The initial $\mathrm{pH}$ of this medium was adjusted to 6 by adding $\mathrm{NaOH}(1 \mathrm{M})$ and $\mathrm{HCl}(1 \mathrm{M})$. After autoclaving, 5\% v/v inoculum was added and incubated at $28^{\circ} \mathrm{C}$ and 150 rpm for 4 days (11). To extract the $F$. fomentarius polysaccharide, after separating the biomass using Whatman paper, absolute ethanol with a ratio of $4: 1$ $\mathrm{v} / \mathrm{v}$ was added to the supernatant. After overnight refrigeration, the polysaccharide precipitates were centrifuged for $10 \mathrm{~min}$ and 10,000 rpm (AWEL/MF20$\mathrm{R} /$ France). The biomass and polysaccharide were lyophilized (OPERON) and the final product was stored at room temperature.

\section{Optimization of Culture Medium Compositions by Taguchi Method}

Taguchi method was used to investigate the effect of independent variables of $\mathrm{MgSO}_{4} .7 \mathrm{H}_{2} \mathrm{O}, \mathrm{pH}$, yeast extract, and inoculum percentage on biomass and polysaccharide production. The Taguchi L9 array was used to examine four variables at three levels (Table 1), the experiments were performed according to this array, and the results were analyzed using Design Expert 11 software (State-Ease, USA).

\section{Biological Assessments}

\section{Antibacterial Activity}

The colony-forming unit (CFU) method was used to evaluate the antibacterial activity of polysaccharides. Staphylococcus aureus (UTMC 1429) and Escherichia coli (PTCC 1269) were obtained from the the Research Center for Technology and Microbial Products of the University of Tehran and Persian Type Culture Collection. Bacteria were cultured in Müller-Hinton Broth (manufactured by Merck, Germany) and after 24 hours of incubation (BINDER, USA), 0.5 McFarland solution was prepared from them. A $5 \%$ solution of each polysaccharide with $0.5 \mathrm{McF}$ arland solution was prepared from each bacterium in a volume of $500 \mu \mathrm{L}$ and kept for 24 hours in a shaker incubator (JAL TAJHIZ, 
Iran) at $37^{\circ} \mathrm{C}$ and $140 \mathrm{rpm}$. The mixture was diluted with phosphate buffer saline $(1: 10)$ and $10 \mu \mathrm{L}$ of it cultured in nutrient agar medium (manufactured by Merck, Germany). In the control state, $10 \mu \mathrm{L}$ of McFarland 0.5 solution of each bacteria was cultured. Then, all culture media were incubated and after 24 hours, bacterial colony count was performed with a gel dock (Quantum, France) (14).

\section{Antioxidant Activity}

DPPH (2,2-diphenyl-1-picryl-hydrazyl-hydrate) test was used to evaluate the antioxidant activity of polysaccharides. After preparing $2 \mathrm{mg} / \mathrm{mL}$ polysaccharide solution in water, the polysaccharide solution and DPPH solution were mixed in a ratio of 1:4 $\mathrm{v} / \mathrm{v}$ and placed in a shaker incubator for 30 minutes (10). Then the absorbance of the samples was measured at $517 \mathrm{~nm}$ with ELISA reader (Carry 100 Bio, Australia) and antioxidant activity was calculated according to the following formula:

$\mathrm{DPPH} \bullet$ scavenging effect $(\%)=[(\mathrm{A} 0-$ sample $\mathrm{A}) / \mathrm{AO}] \times 100$

\section{A0: Adsorption of DPPH solution at $517 \mathrm{~nm}$}

sample A: Absorption of the test sample at $517 \mathrm{~nm}$

\section{Cytotoxicity Assay}

MKN45, AGS, A549, KYSE-30, and 5637 cancer cell lines were purchased from the Iranian Genetic Resources Center. Cancer cells were cultured in RPMI 1640 medium with 2 mM L-glutamine and 15\% FBS and stored in a $\mathrm{CO}_{2}$ incubator at $37^{\circ} \mathrm{C}$. To evaluate the effect of polysaccharide, its solution was prepared in sterile water $(1 \mathrm{mg} / \mathrm{mL})$ and used at specific concentrations $(50,100,200 \mu \mathrm{g} / \mathrm{mL})$ to treat cells for 24 and 72 hours. In this experiment, positive control included culture medium and negative control included untreated cell culture. MTS test was used to evaluate cell viability. A total of 2000 cancer cells were cultured in each well of 96 well plates ( 24 hours). After treatment with specified concentrations of polysaccharide for 24 and 72 hours, $10 \mu \mathrm{M}$ MTS solution (1:10 diluted in RPMI 1640) was added to each well and incubated for 3 hours (15). Then, adsorption of each sample was read at $495 \mathrm{~nm}$ using ELISA reader (Carry 100 Bio, Australia) and the cell viability percentage was calculated using the following formula:

Cell viability: Sample absorbance/ Control absorbance $\times 100$

\section{Statistical Analysis}

Data were analyzed statistically by ANOVA method using Design Expert, version 11 (State Ease, USA). Pvalues below $0.05 \quad(P<0.05)$ were considered to be statistically significant.

\section{Results}

The results of initial experiments on the biomass and polysaccharide production of the $F$. fomentarius showed that four days after the cultivation of the fungus in the desired culture medium, biomass production reaches $15 \mathrm{~g} / \mathrm{L}$ and polysaccharide production reaches $4.06 \mathrm{~g} / \mathrm{L}$. Therefore, the culture medium that includes glucose, peptone, malt extract, yeast extract, $\mathrm{MgSO}_{4} .7 \mathrm{H}_{2} \mathrm{O}$, and $\mathrm{KH}_{2} \mathrm{PO}_{4}$ is a suitable culture medium for the growth and production of polysaccharides of this fungus.

\section{Optimization of Biomass and Polysaccharide Production}

According to the preliminary results, the optimization of the culture medium was designed and performed using the Taguchi method with four factors at three levels (Table 1).

Table 1. Taguchi L9 array test design layout and results obtained for the production of biomass and polysaccharide of $F$. fomentarius

\begin{tabular}{|c|c|c|c|c|c|c|}
\hline \multicolumn{4}{|c|}{ Parameters } & \multicolumn{3}{|c|}{ Response } \\
\hline Runs & $\mathrm{A}: \mathrm{MgSO}_{4} .7 \mathrm{H}_{2} \mathrm{O}(\mathrm{g} / \mathrm{L})$ & B:pH & $\begin{array}{c}\text { C:Yeast extract } \\
(\mathrm{g} / \mathrm{L})\end{array}$ & $\begin{array}{c}\text { D:Inoculum (\% } \\
\text { v/v) }\end{array}$ & $\begin{array}{l}\text { Biomass } \\
(\mathrm{g} / \mathrm{L})\end{array}$ & Polysaccharide (g/L) \\
\hline 1 & 2.5 & 8 & 2 & 5 & 9.890 & 4.498 \\
\hline 2 & 2.5 & 4 & 4 & 10 & 10.560 & 2.337 \\
\hline 3 & 1 & 4 & 2 & 3 & 11.840 & 1.274 \\
\hline 4 & 1 & 6 & 4 & 5 & 14.522 & 2.785 \\
\hline 5 & 4 & 4 & 6 & 5 & 11.626 & 4.201 \\
\hline 6 & 1 & 8 & 6 & 10 & 9.920 & 2.878 \\
\hline 7 & 2.5 & 6 & 6 & 3 & 14.690 & 3.573 \\
\hline 8 & 4 & 8 & 4 & 3 & 12.150 & 5.410 \\
\hline 9 & 4 & 6 & 2 & 10 & 7.600 & 3.110 \\
\hline
\end{tabular}


Figure 1 (A) shows a comparison chart of the amount of biomass produced in each experiment and the amount predicted by the software. As can be seen, these results are very close to the data predicted by the software. $\mathrm{R}^{2}$ for biomass production is $90.54 \%$. Analysis of the results with ANOVA using Design Expert showed that inoculum have a significant effect $(P<0.05)$ on the biomass production of $F$. fomentarius. The linear model for biomass production based on each of the variables is as follows:

Biomass: $10.44-1.44 \mathrm{~A}-0.4200 \mathrm{~B}+1.55 \mathrm{C}-3.18 \mathrm{D}$

In this equation (A) is the concentration of $\mathrm{MgSO}_{4} .7 \mathrm{H}_{2} \mathrm{O}$, (B) $\mathrm{pH}$, (C) yeast extract, and (D) the percentage of inoculum. The two-dimensional and three-dimensional diagrams of the effect of variables on biomass production are shown in Figure 1.

Table 1. Analysis of variance and regression coefficients for biomass production of $F$. fomentarius.

\begin{tabular}{|c|c|c|c|c|c|}
\hline Source & Sum of squares & df & Mean square & F-value & P-value \\
\hline Model & 41.69 & 4 & 10.42 & 9.57 & 0.0251 \\
\hline $\mathrm{MgSO}_{4} \cdot 7 \mathrm{H}_{2} \mathrm{O}(\mathrm{A})$ & 5.55 & 1 & 5.55 & 5.55 & 0.0868 \\
\hline pH (B) & 1.06 & 1 & 1.06 & 0.9722 & 0.3800 \\
\hline Yeast extract (C) & 6.41 & 1 & 6.41 & 5.88 & 0.0723 \\
\hline Inoculum (D) & 28.67 & 1 & 28.67 & 26.34 & 0.0068 \\
\hline Residual & 4.35 & 4 & 1.09 & & \\
\hline Cor Total & 46.05 & 8 & & & \\
\hline
\end{tabular}

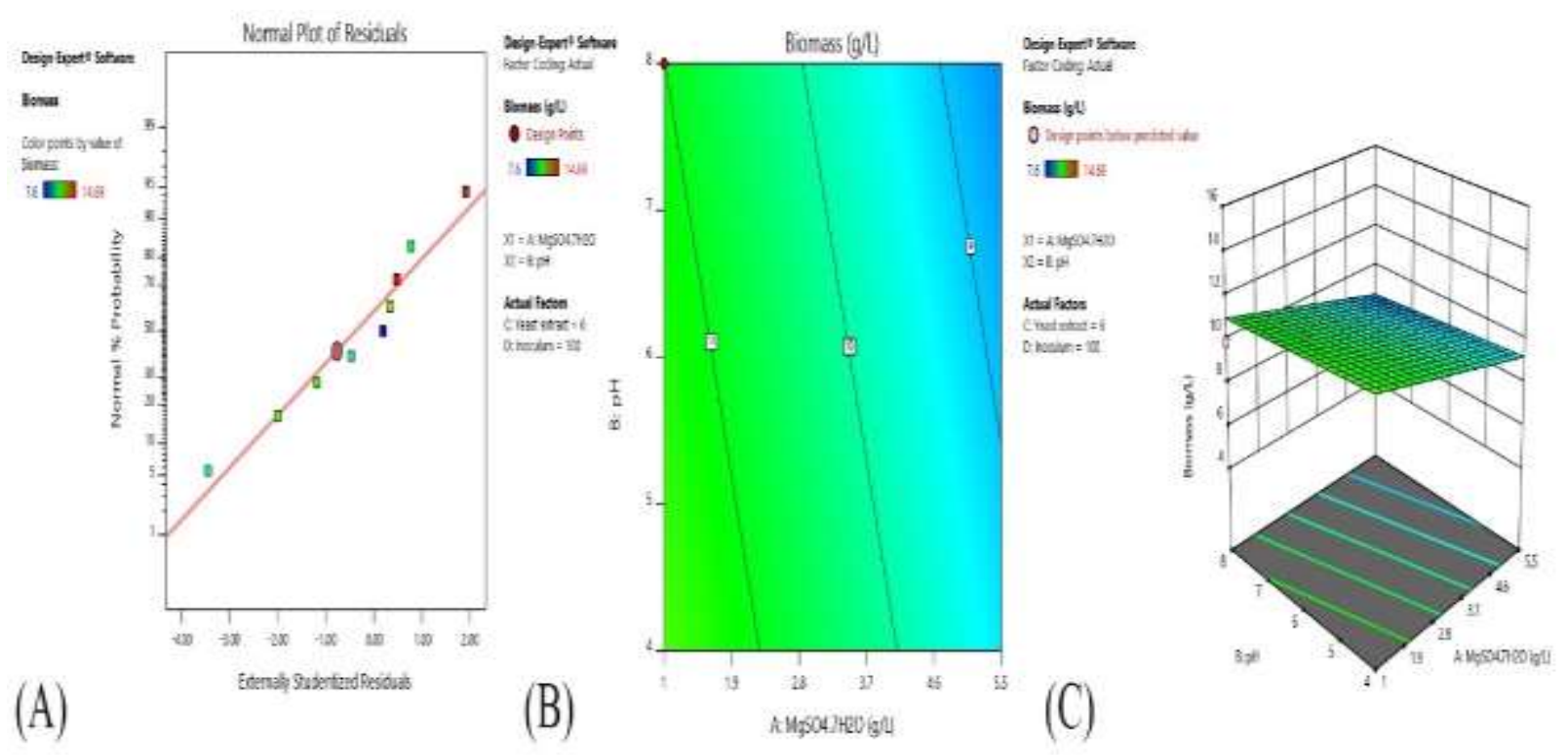

Figure 1. Comparison diagram of produced and predicted biomass (A), two-dimensional diagram (B) and three-dimensional (C) effect of $\mathrm{MgSO}_{4} .7 \mathrm{H}_{2} \mathrm{O}$ and initial $\mathrm{pH}$ on $\mathrm{F}$. fomentarius biomass production.

A comparison of the amount of polysaccharide produced in each experiment and the amount predicted by the software showed that these results are very close. $\mathrm{R}^{2}$ for biomass production is $91.68 \%$. Analysis of the results with ANOVA using Design Expert showed that concentrations of $\mathrm{MgSO}_{4} .7 \mathrm{H}_{2} \mathrm{O}$ and initial $\mathrm{pH}$ have a significant effect $(P<0.05)$ on the production of polysaccharides of $F$. fomentarius. The linear model for polysaccharide production based on each of the variables is as follows:

$:($ eq.4)

Polysaccharide $=3.71+1.45 \mathrm{~A}+0.8292 \mathrm{~B}+0.4427 \mathrm{C}-0.6025 \mathrm{D}$

In this equation (A) is the concentration of $\mathrm{MgSO}_{4} .7 \mathrm{H}_{2} \mathrm{O}$, (B) $\mathrm{pH}$, (C) yeast extract and (D) the 
percentage of inoculum. The two-dimensional and three-dimensional diagrams of the effect of variables on polysaccharide production are shown in Figure 2.

Table 2 . Analysis of variance and regression coefficients for polysaccharide production of $F$. fomentarius.

\begin{tabular}{|c|c|c|c|c|c|}
\hline Source & Sum of squares & df & Mean square & F-value & P-value \\
\hline Model & 11.25 & 4 & 2.81 & 11.02 & 0.0196 \\
\hline $\mathrm{MgSO}_{4} .7 \mathrm{H}_{2} \mathrm{O}(\mathrm{A})$ & 5.58 & 1 & 5.58 & 21.84 & 0.0095 \\
\hline pH (B) & 4.13 & 1 & 4.13 & 16.16 & 0.0159 \\
\hline Yeast extract (C) & 0.5227 & 1 & 0.5227 & 2.05 & 0.2257 \\
\hline Inoculum (D) & 1.03 & 1 & 1.03 & 4.02 & 0.1153 \\
\hline Residual & 1.02 & 4 & 0.2553 & & \\
\hline Cor Total & 12.27 & 8 & & & \\
\hline
\end{tabular}
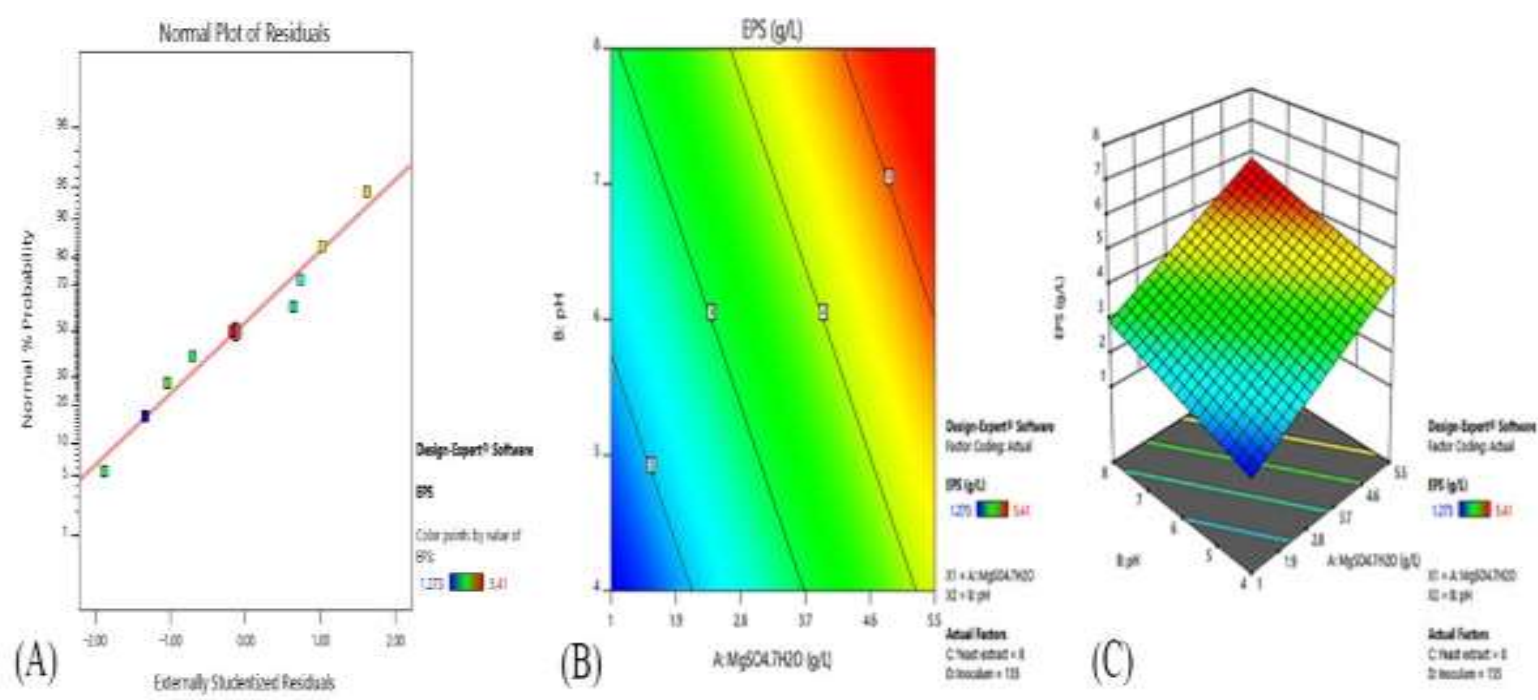

Figure 2. Comparison diagram of produced and predicted polysaccharide (A), two-dimensional diagram (B) and three-dimensional (C) effect of $\mathrm{MgSO}_{4} .7 \mathrm{H}_{2} \mathrm{O}$ and initial $\mathrm{pH}$ on $\mathrm{F}$. fomentarius polysaccharide production.

\section{Biological Assessments}

\section{Antibacterial Activity}

The antibacterial activity of polysaccharide produced by $F$. fomentarius in Taguchi experiments was tested against Gram-positive bacteria $S$. aureus and Gramnegative bacteria $E$. coli. Bacterial colony count using a gel dock device showed that in the control sample of both strains, bacterial growth is $100 \%$. Colony counts showed that the polysaccharide of this fungus has an inhibitory effect on bacterial growth. This effect is greater on the gram-positive bacteria S. aureus. Sample 7 with $50 \%$ inhibition of $S$. aureus had the highest inhibitory effect $(P<0.05)$. It can also inhibit the growth of $E$. coli by up to $24 \%$. The highest inhibitory effect on $E$. coli was observed in sample 3 (25\%). There was no significant difference between the antibacterial activities of polysaccharides on $E$. coli. The Figure 3 (A) shows the antibacterial activity of the polysaccharide of the fungus F. fomentarius.

\section{Antioxidant Activity}

The antioxidant activity of polysaccharides produced by $F$. fomentarius in Taguchi experiments was investigated using DPPH free radicals. When the antioxidant substance donates protons to this free radical, its absorption in $517 \mathrm{~nm}$ decreases; this decrease indicates the level of antioxidant activity. The antioxidant activity of polysaccharides produced by this fungus varies in different environments (Figure 3, B). Analysis of DPPH results showed that the antioxidant activity in polysaccharide produced in environment 7 shows the highest antioxidant activity (16.11\%). The lowest antioxidant activity is related to sample 2 .

\section{Cytotoxicity Assay}

Biological assessments in previous stages showed that sample 7 has the most biological activity; therefore, this sample was used to evaluate cytotoxicity. In this study, the antiproliferative effect of polysaccharide of this 
fungus in different concentrations on 5 cancer cell lines MKN-45, AGS, A549, KYSE-30 and 5637 was investigated using MTS test (Figure 4). In general, F. fomentarius polysaccharide inhibits the growth of all studied cancer cells significantly $(P<0.05)$. After 24 hours, the antiproliferative effect of polysaccharide at a concentration of $50 \mu \mathrm{g} / \mathrm{mL}$ on AGS was significantly $(P<0.05)$ greater than that KYSE-30 and 5637 , but no difference was observed between the antiproliferative effect of polysaccharide in other cancer cell lines. At a concentration of $100 \mu \mathrm{g} / \mathrm{mL}$ polysaccharide had the highest antiproliferative effect on the AGS cell line and it was significantly higher than other cell lines $(P<0.05)$. At a concentration of $200 \mu \mathrm{g} / \mathrm{mL}$, the polysaccharide has a significant antiproliferative effect on A549 cancer cells compared to other cell lines, and it inhibits the growth of this cell by more than $50 \%$. After 72 hours, there was no significant difference between the antiproliferative effects of polysaccharide on the cancer cell lines. At a concentration of $100 \mu \mathrm{g} / \mathrm{mL}$ polysaccharide of $F$. fomentarius had the most antiproliferative effect on 5637 cells and it was significantly different from other cell lines $(P<0.05)$. At a concentration of $200 \mu \mathrm{g} / \mathrm{mL}$, polysaccharide inhibits the growth of A549, KYSE-30 and 5637 cells by up to $40 \%$ and has a significant difference compared to this effect on MKN-45 and AGS cells $(P<0.05)$.
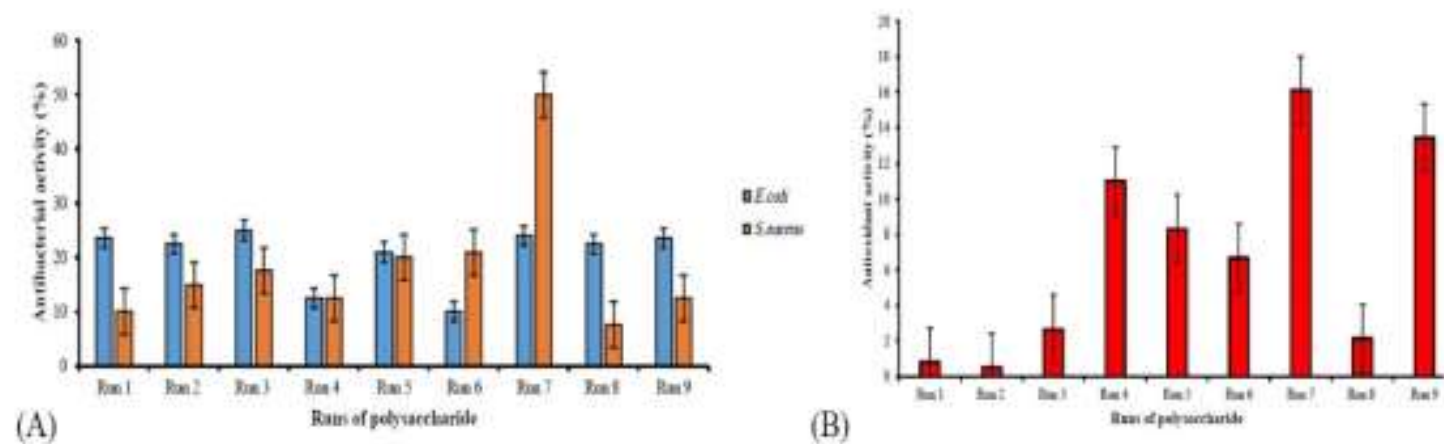

Figure 3. Antibacterial (A) and antioxidant (B) activity of polysaccharide obtained from the Taguchi L9 array.
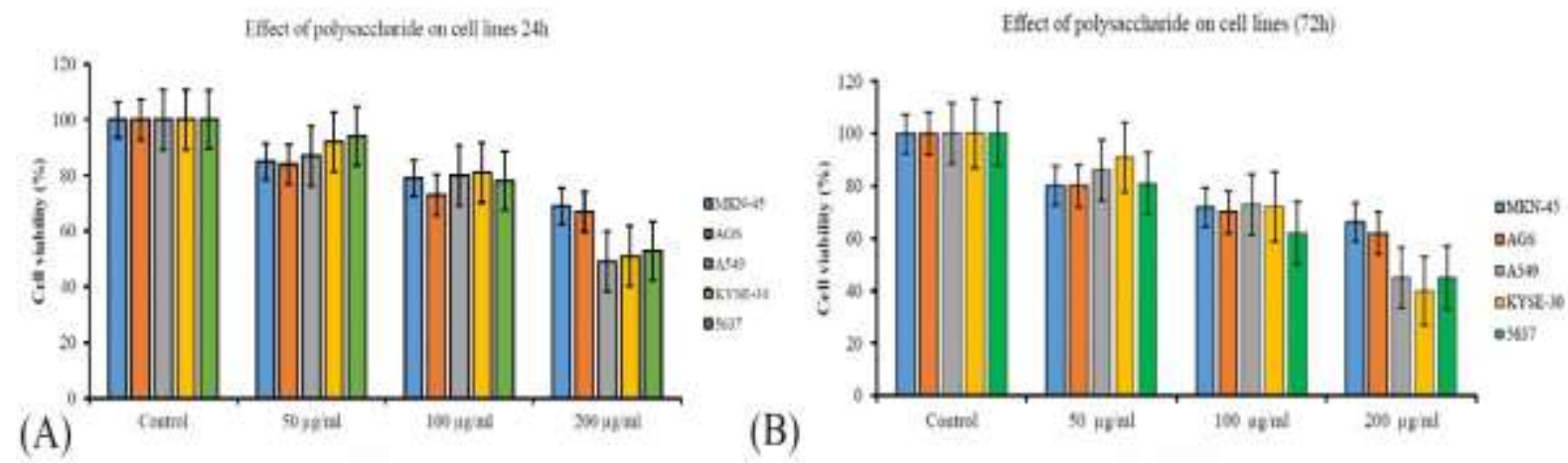

Figure 4. Cell viability diagram of 5 cancer cell lines treated with F. fomentarius polysaccharide after 24 (A) and 72 hours (B

\section{Discussion}

In this study, the optimization of biomass and polysaccharide production of the medicinal fungus $F$. fomentarius and its polysaccharide biological properties were investigated. As observed in previous studies (4) and this study, the suitable culture medium for this fungus includes glucose, peptone, malt extract, yeast extract, $\mathrm{MgSO}_{4} \cdot 7 \mathrm{H}_{2} \mathrm{O}$, and $\mathrm{KH}_{2} \mathrm{PO}_{4}$. Studies show that peptone in this environment plays an important role in increasing the growth and production of fungal enzymes (16). Optimization of culture medium using the Taguchi method showed that $\mathrm{MgSO}_{4} .7 \mathrm{H}_{2} \mathrm{O}$ concentration and initial $\mathrm{pH}$ have a significant effect $(P<0.05)$ on polysaccharide production of this fungus. With the increase of $\mathrm{MgSO}_{4} .7 \mathrm{H}_{2} \mathrm{O}$ and the initial $\mathrm{pH}$, the production of polysaccharide of $F$. fomentarius increases. $\mathrm{pH}$ is involved in permeability, cell membrane function, and production of secondary metabolites (11). Magnesium is an important element in the metabolism of fungi and the stability of cell membranes. It is also involved in DNA replication, cell division, and many enzymatic reactions $(11,17,18)$. Chen et al. (2008), increased the polysaccharide production of this fungus $(3.64 \mathrm{~g} / \mathrm{L})$ by optimizing the culture medium. In this study, under optimal conditions ( $4 \mathrm{~g} / \mathrm{L} \mathrm{MgSO}_{4} .7 \mathrm{H}_{2} \mathrm{O}$, initial $\mathrm{pH}=8$ ), 
the production of polysaccharide of the $F$. fomentarius reached $5.410 \mathrm{~g} / \mathrm{L}$. This amount is 1.5 times the production of polysaccharides in common fungal culture medium (PDB) (11).

Studies show that physicochemical conditions of the culture medium such as carbon source, nitrogen source, mineral sources, $\mathrm{pH}$ and culture temperature play an important role in the biological activity of fungal metabolites $(19,20)$. F. fomentarius polysaccharide inhibits the growth of $S$. aureus and $E$. coli by $50 \%$ and $25 \%$, respectively. Polysaccharide of this fungus contains terpenoids and polyphenols with antibacterial activity and with their increase this activity increases (21). Studies show that the type and volume of solvent used to extract polysaccharides play a role in the content of polyphenols. The use of polar solvents such as ethanol increases polyphenols (10, 22). Kalyoncu et al. (2010), found that the antioxidant activity of the polysaccharide of the $F$. fomentarius was $5.97 \%$. By optimizing the culture conditions in this study, the antioxidant activity of polysaccharide increased to $16.11 \%$. Most biological properties such as antioxidant, antibacterial, and antiproliferative activity are observed when the initial $\mathrm{pH}$ of the fungal culture medium is in the range of 5-7 (23). The difference between the initial $\mathrm{pH}$ and the composition of the culture medium causes a difference in the phenolic content of the polysaccharide. These compounds are associated with antioxidant activity and reduction of $\mathrm{OH}^{*}, \mathrm{O}_{2}{ }^{\circ}$, and $\mathrm{NO}^{*}$ radicals (24). Investigations in this study and previous studies (4, 5, 11) show that this polysaccharide has an antiproliferative effect on cancer cells, but this effect varies in cell lines and increases with increasing of the concentration. The antiproliferative effect of $F$. fomentarius polysaccharide was observed (KYSE-30> A549 $\geq 563749>$ AGS $>$ MKN-45) after 72 hours. In the treatment of KYSE-30 cells with $200 \mu \mathrm{g} / \mathrm{mL}$ polysaccharide, cell viability reaches $40 \%$ after 72 hours. Also, after 72 hours, the life expectancy of A549 and 5637 cancer cells was $45 \%$ and that of MKN-45 and AGS cancer cells was $66 \%$ and $62 \%$, respectively. Today, the polysaccharides of the fungi like Ganoderma lucidum and Tinea versicolor are used as supplements in the treatment of various cancers. The anti-cancer activity of these polysaccharides includes inhibiting the growth of cancer cells and stimulating the immune system (25). The antiproliferative activity of fungal polysaccharides is related to the chemical structure and composition of their monosaccharides. The polysaccharide of $F$. fomentarius is rich in beta- glucan, which has anti-cancer properties. This compound destroys transcription proteins in cancer cells and arrests the cell cycle in the G1 phase. It also induces apoptosis in cells by damaging organelles, the cell nucleus, and fragmenting DNA $(10,26,27,28)$. The results of this study showed that the polysaccharide of the medicinal $F$. fomentarius, due to its antibacterial, antioxidant and antiproliferative properties, can be a suitable option for the treatment of many diseases and can be used as a dietary supplement.

\section{Conclusion}

In this study, the production of biomass and polysaccharide of the Iranian medicinal $F$. fomentarius was optimized using the Taguchi method. Inoculum percentage had significant effects on biomass production and $\mathrm{MgSO}_{4} .7 \mathrm{H}_{2} \mathrm{O}$ concentration and initial $\mathrm{pH}$ had significant effects $(P<0.05)$ on polysaccharide production of this fungus and under optimal conditions (4 g/L $\mathrm{MgSO}_{4} .7 \mathrm{H}_{2} \mathrm{O}$, initial $\mathrm{pH}=8$ ) polysaccharide production increases 1.5 times and reaches $5.410 \mathrm{~g} / \mathrm{L}$. Biological assessments showed that this polysaccharide inhibits the growth of $S$. aureus and $E$. coli $50 \%$ and $25 \%$, respectively $(P<0.05)$. Also, its antioxidant activity increases 2 times and reaches $16.11 \%$. The antiproliferative effect of $F$. fomentarius polysaccharide is different on different cancer cells and increases with increasing concentration. The cell viability of KYSE-30 treatment with $200 \mu \mathrm{g} / \mathrm{mL}$ polysaccharide, reaches $40 \%$ after 72 hours. Also, the cell viability of $A 549$ and 5637 cancer cells is $45 \%$ and the cell viability of MKN-45 and AGS cancer cells is $66 \%$ and $62 \%$, respectively.

\section{Acknowledgment}

This article is taken from the master's thesis (19/06/28690), which would like to thank all the professors who helped us in the Faculty of New Sciences and Technologies, University of Tehran.

\section{Funding}

Funding for this study was provided by the authors in collaboration with the University of Tehran.

\section{Conflict of Interest}

Authors declared no conflict of interests. 


$$
\begin{aligned}
& \text { مجله ميكروبشناسى يزشكى ايران }
\end{aligned}
$$

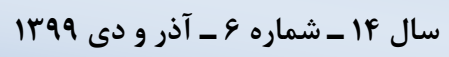

\title{
بهينه سازى شرايط توليد بلى ساكاريد زيست فعال از نومس فومنتاريوس و بررسى فعاليت ضدباكتريايى و ضدسرطانى
}

\author{
هاله الوندى'، اشرف السادات حاتميان زارمى" "، بهمن ابراهيمى حسين زاده׳، زهرا بيكم مختارى حسينى
}

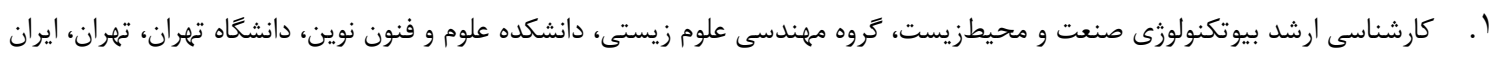

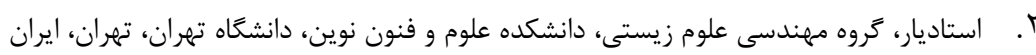
r.

\section{جكسبـ}

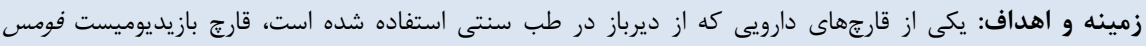

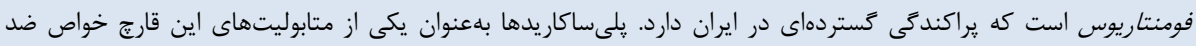

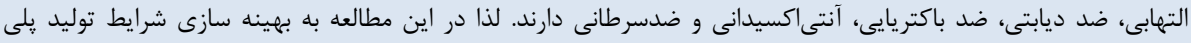

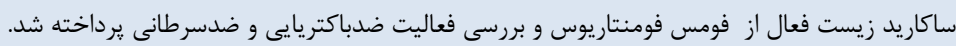

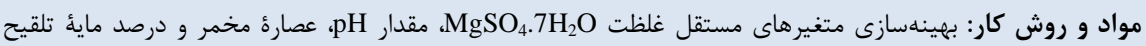

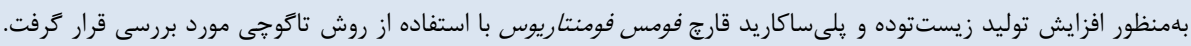

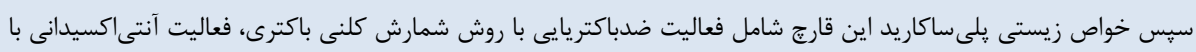

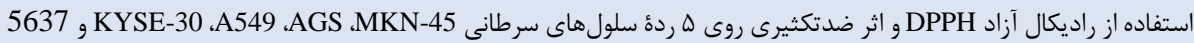

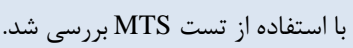

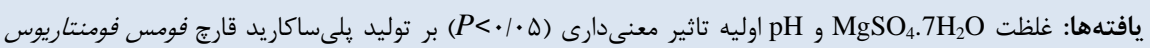

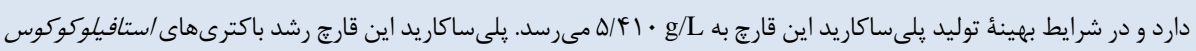

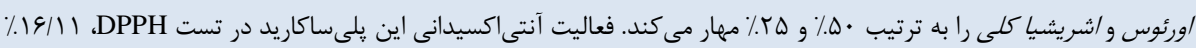

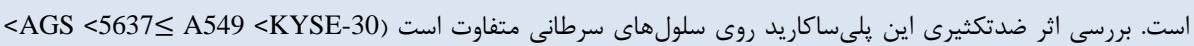

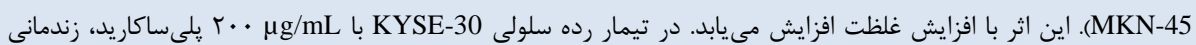

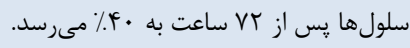

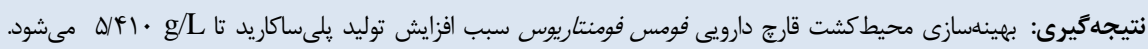

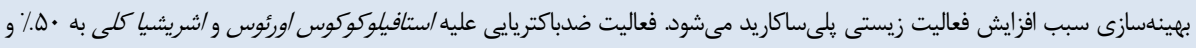

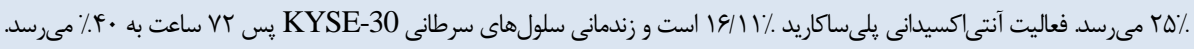

$$
\text { كليد وازهها: فومس فومنتاريوس، بهينهاساز، تاكوجى، ضدباكتريايى، آنتىاكسيدانى، ضدسرطانى }
$$

اطلاعات مقاله

تاريخجهُ مقاله

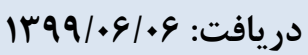

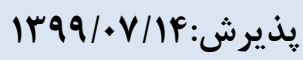

انتشار آنلاين:

موضوع:بيوتكنولوزى ميكروبى

نويسندهُ مسئول:

اشرف السادات حاتميان زارمى،

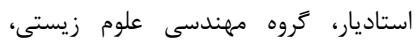

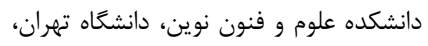

تهران، ايران

ايميل:

hatamian_a@ut.ac.ir

مقدمه

متعدد، تنوع زيستى مناسب قارجهاى دارويى در ايران و ارزش اقتصادى متابوليتهاى اين قارجها لزوم توجه به اين شاخه از علوم زيستى را نشان مىدهد (Y). از ميان قارجهاى دارويى، قارج بازيديوميست فومس فومنتاريوس از ديرباز در درمان بيمارىهاى كوارشى، سيروز كبدى، و انواع سرطانها استفاده مىشده است. يراكندگى اين قارج در ايران گسترده است و تاكنون وجود آن در
سابقهُ استفاده از قارتهاى دارويى در كشورهاى شرق آسيا به هزاران سال قبل برمى گردد. بسيارى از اين قارتها امروزه نيز در درمان

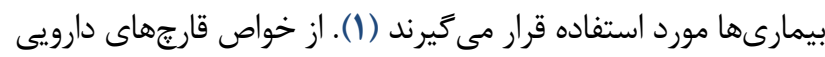
مىتوان به تحريك تكثير لنفوسيتها، كاهش تكثير سلولهاى

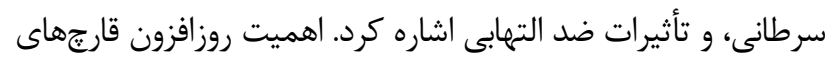

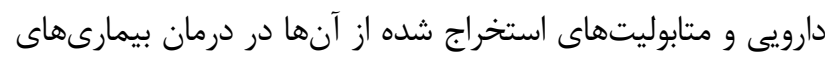


جداسازى شد. در هر مورد نمونهُ قارجى به شكل سالم، كامل و مناسب

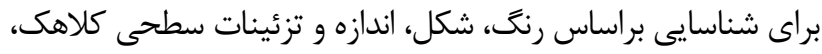

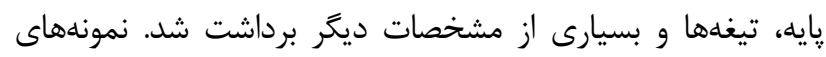

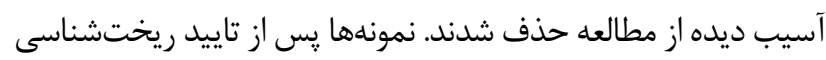
توسط قارجشناسان در دماى \& درجه سلسيوس نكمهدارى شده است.

\section{شناسايى و كشت قارج فومس فومنتاريوس و استخراج يلىساكاريد} ميسليوم قارج فومس فومنتاريوس در محيط PDA (توليد شده در شركت مرك كشور آلمان) در يك ظرف يترى كشت شد و به مدت هارئ ه

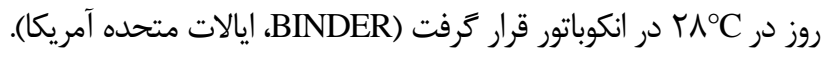

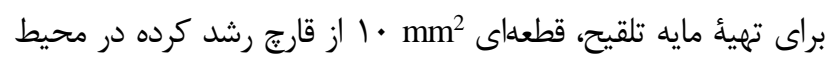

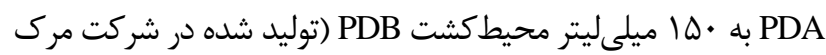

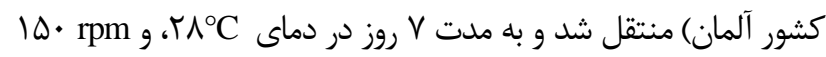

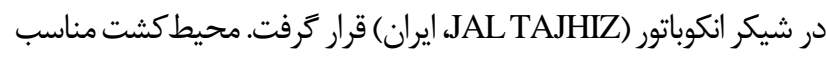

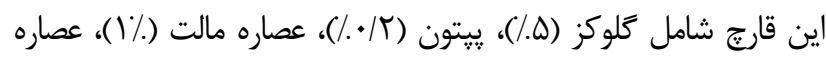

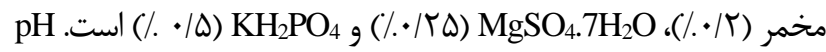

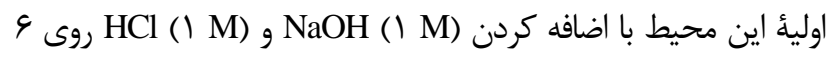

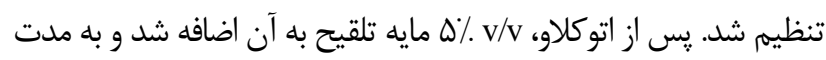

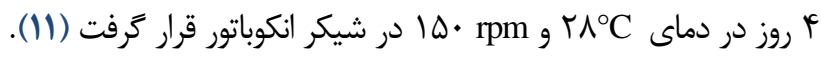

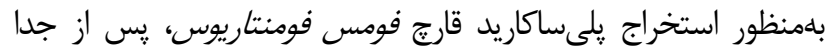

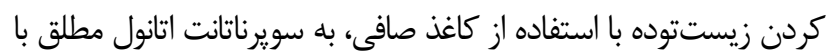

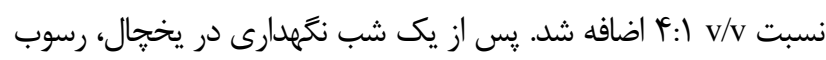

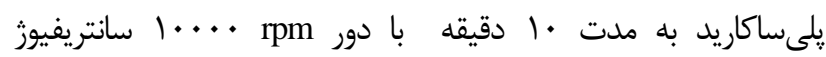
شد. زيستوده و ويلىساكاريد ليوفيليزه (AWEL/MF20-R) شدند (OPERON) و محصول نهايى در دماى اتاق نتحهدارى شد.

\section{بهينهسازى تركيبات محيط كشت با روش تاكوجى}

بلمنظور بررسى اثر متغيرهاى مستقل غلظت

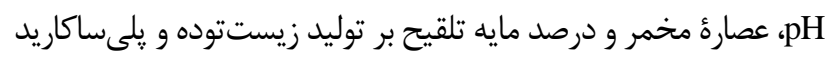

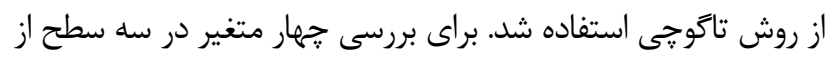
آرايه L9 تاكوجى استفاده شد (جدول ()، آزمايشها مطابق اين آرايه

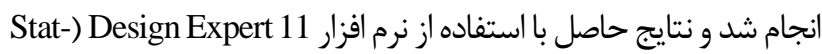
Ease، ايالات متحده آمريكا) مورد بررسى قرار كَرفتند.

\section{ارزيابى هاى زيستى فعاليت ضدباكتريايى}

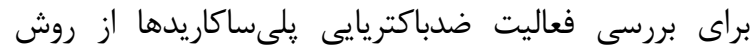

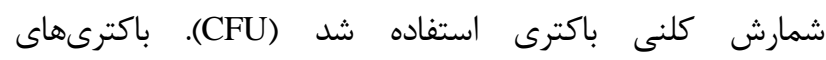
استافيلوكوكوس /ورئوس (UTMC 1429) و /شريشيا كلى (

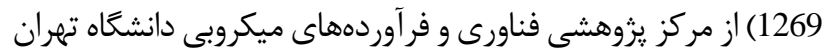

استانهاى مازندران، كلستان، گيلان، اصفهان، تهران، كردستان،

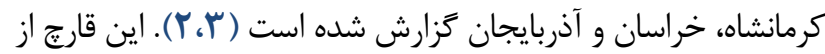

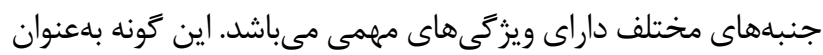

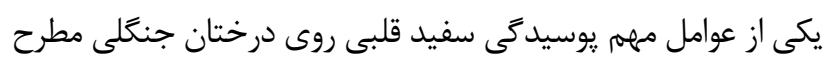
است. عصارء آن خواص آنتىاكسيدانى و ضدسرطانى دارد (ب).

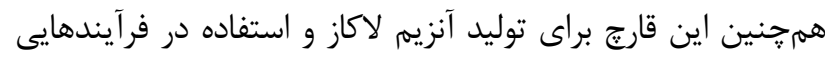

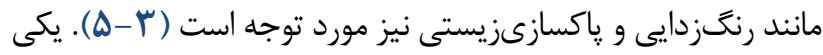

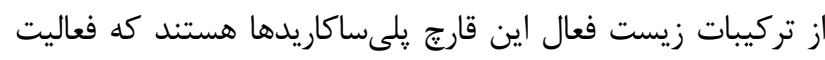

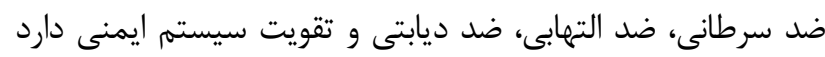
(F). يلىساكاريد بتاكلوكان فومس فومنتاريوس از ركزايى تومور و متاستاز جلوكيرى مى كند (Y، V). اثر ضد تكثيرى اين يلىساكاريد

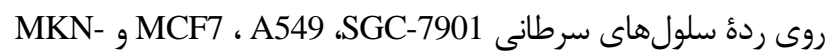

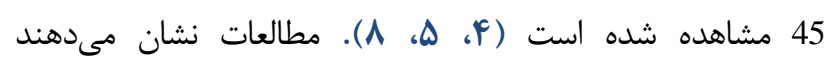

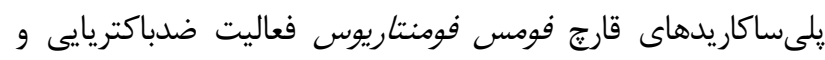

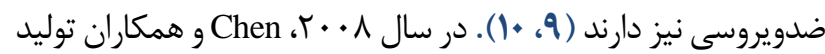

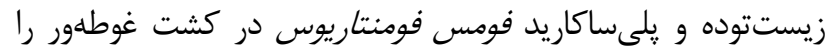

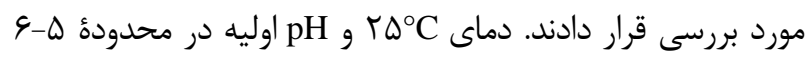

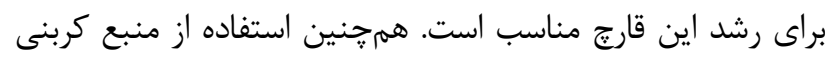
كلوكز، منبع نيتروزنى عصاره مخمر، بهبود رشد زيستتوده و افزايش توليد يلىساكاريد مىشود (II).

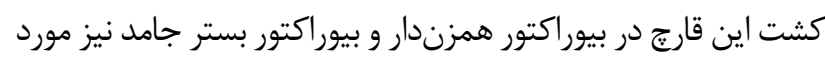

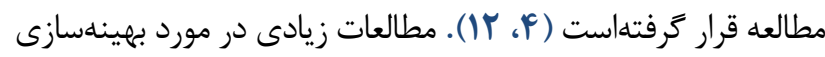
محيطكشت مناسب ساير قارجها و توليد متابوليت آنها با كمى روشهاى آمارى صورت كرفته است. يكى از اين روشهاى آمارى،

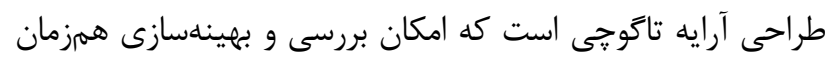

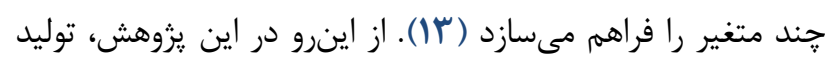

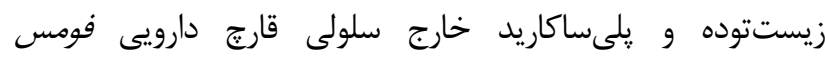

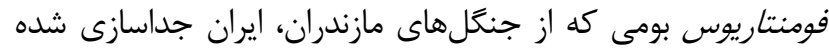

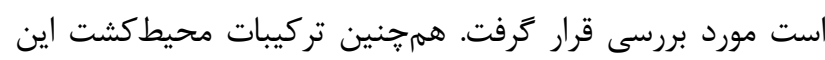

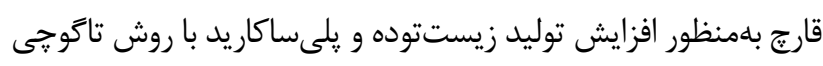
بهينهسازى شد. سيس فعاليتهاى زيستى يلى ساكاريد شامل فعاليت ضدباكتريايى، آنتىاكسيدانى و سميت سلولى بررسى ترى برديد.

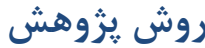

\section{جمع آورى نمونههاى قارج و سويه استاندارد}

در اين مطالعه مقطعى-توصيفى، قارج فومس فومنتاريوس از

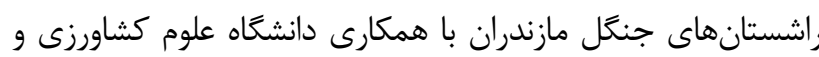

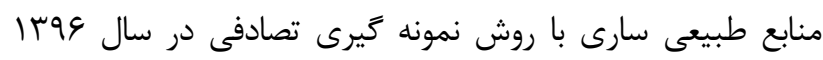


سرطانى در هر خاهك يليت צو خانه كشت داده شد (TI ساعت). يس

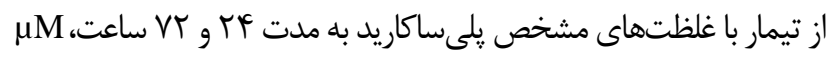

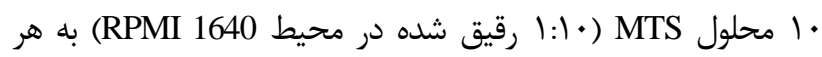

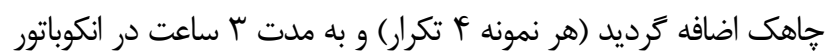
قرار كرفت (ها). سيس هر نمونه جذب با استفاده از دستخاه خوانشگر

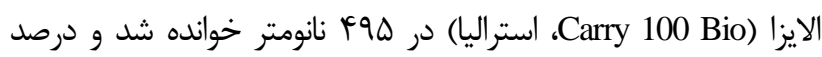
زندمانى سلولها با استفاده از فرمول زير محاسبه گرديد:

معادله (r):

• • ( × جذب كنترل/ جذب نمونه : درصد زندمانى سلولى

\section{تجزيه و تحليل آمارى}

دادهها با استفاده از Stat-Ease) Design Expert 11 ايالات متحده آس آمريكا) و روش آناليز واريانس يك طرفه (ANOVA) مورد تجزيه و تحليل

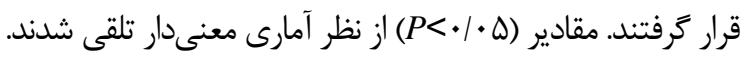

\section{يافتهها}

نتايج آزمايشهاى اوليه روى توليد زيستتوده و يلىساكاريد قارج دارويى فومس فومنتاريوس نشان داد، جهار روز يس از كشت

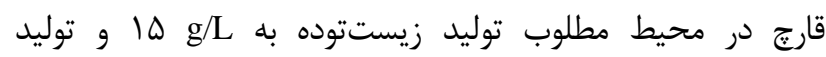

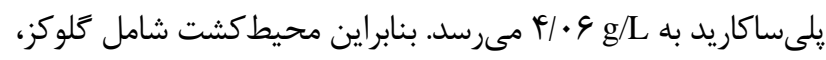
״يּتون، عصاره مالت، عصاره مخمر، $\mathrm{KH}_{2} \mathrm{PO}_{4}$ و $\mathrm{MgSO}_{4} .7 \mathrm{H}_{2} \mathrm{O}$ محيطى مناسب براى رشد و توليد يلىساكاريد اين قارتج مىباشد.

\section{بهينهسازى توليد زيست توده و زيلىساكاريد}

با توجه به نتايج اوليه، بهينهسازى محيط كشت با باستفاده از روش

تاگوجى با جهار فاكتور در سه سطح طراحى و اجرا شد (جدول (). در شكل I (A) نمودار مقايسه ميزان زيستتوده توليد شده در هر آزمايش و مقدار ريشبينى شده توسط نرمافزار آورده شده است.

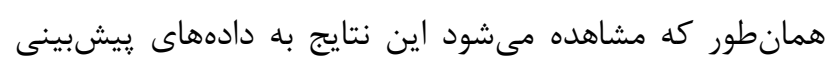

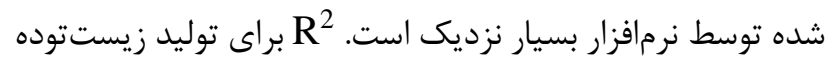
F نشان مىدهد، درصد مايه تلقيح اثر Design Expert 11 معنى فومنتاريوس دارد (جدول r). مدل خطى براى توليد زيست توده بر

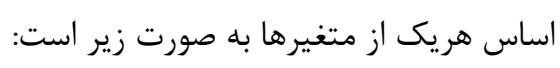

معادله (ז): (1) (n)

Biomass: $10.44-1.44 \mathrm{~A}-0.4200 \mathrm{~B}+1.55 \mathrm{C}-3.18 \mathrm{D}$
و مركز كلكسيون ميكرواركانيسمهاى صنعتى ايران تهيه شدند. اين باكترىها در محيط مولر هينتون براث (شركت مرك كشور آلمان)

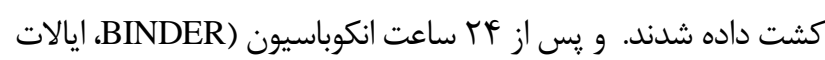

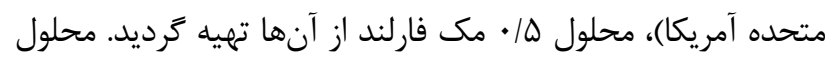

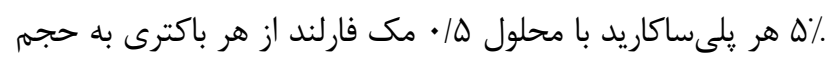

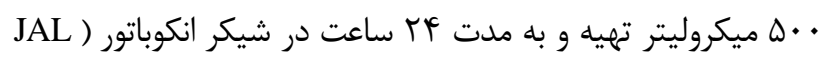

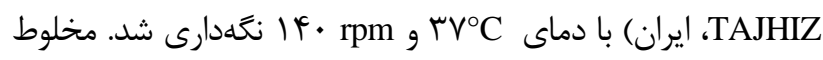
فوق با بافر سالين فسفات (PBS) رقيق شد (• (: (1) و • 1 ميكروليتر آن در محيط نوترينت آتار (توليد شده در شركت مرك كشور آلمان)

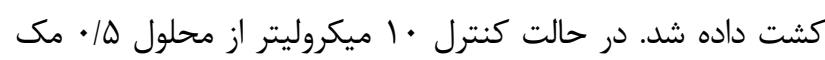

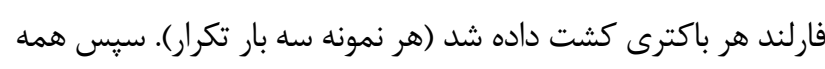

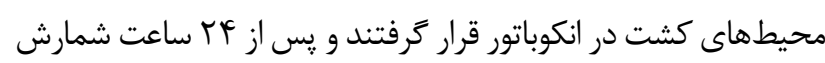
كلنى باكترى با دستعاه زل داك (Quantum، فرانسه) انجام شد (IF).

\section{فعاليت آنتى اكسيدانى}

بلمنظور بررسى فعاليت آنتىاكسيدانى يلىساكاريدها از تست استفاده شد. پس از تهيه محلول DPPH آب مقطر، محلول يلى

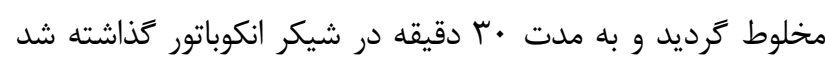

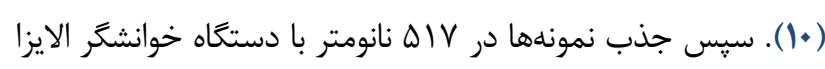
Carry 100 Bio) توجه به فرمول زير محاسبه گرديد:

معادله (1):

$\mathrm{DPPH} \bullet$ scavenging effect $(\%)=[(\mathrm{A} 0-\mathrm{A}$ sample $) / \mathrm{A} 0] \times 100$ A0: جذب محلول DPPH در IV جاه نانومتر A sample بررسى سميت سلولى

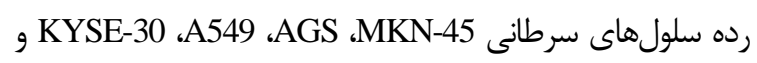

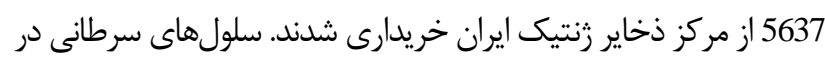

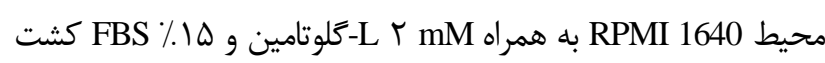

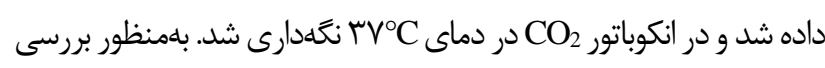

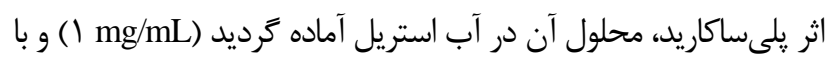

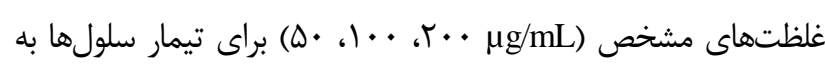

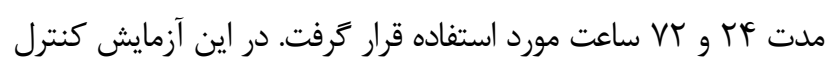
مثبت شامل محيطكشت و كنترل منفى كشت سلولى فاقد تيمار بود. بdمنظور بررسى زندمانى سلولى از تست MTS استفاده شد. • . . ب سلول 
جدول ا. جيدمان طراحى آزمايش آرايه L9 تاكوجى و نتايج بدست آمده براى توليد زيست توده و يلى

\begin{tabular}{|c|c|c|c|c|c|c|}
\hline \multicolumn{4}{|c|}{ ياسخ } & \multicolumn{3}{|c|}{ متغير ها } \\
\hline يلىساكاريد(g/L) & زيست توده (g/L) & (v/v) مايه تلقيح:D & C عصاره مخمر (g/L) & B:pH & $\mathrm{A}: \mathrm{MgSO}_{4} .7 \mathrm{H}_{2} \mathrm{O}(\mathrm{g} / \mathrm{L})$ & 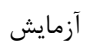 \\
\hline$f / 4 q 1$ & १/^१. & $\Delta$ & r & $\wedge$ & $r / \Delta$ & 1 \\
\hline עrr/r & $1 \cdot 1 \Delta G$. & 1. & f & f & $T / \Delta$ & r \\
\hline I/TVF & II/AF. & r & r & f & 1 & r \\
\hline$r / V \wedge \Delta$ & IF/OT & $\Delta$ & f & 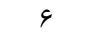 & 1 & f \\
\hline$F / r \cdot 1$ & 11/दY & $\Delta$ & 4 & f & f & $\Delta$ \\
\hline r/AVA & १/१५. & 1. & 4 & $\wedge$ & 1 & 4 \\
\hline$r / \Delta V r$ & $14 / 9 q$. & r & 4 & 4 & $r / \Delta$ & v \\
\hline$\Delta / f)$. & $\mid T / 1 \Delta$. & $r$ & f & $\Lambda$ & f & $\wedge$ \\
\hline $\mathrm{r} / 1$. & $V / 9 .$. & 1. & r & 9 & f & 9 \\
\hline
\end{tabular}

جدول r. آناليز واريانس و ضرايب ركرسيون براى توليد زيستتوده قارج فومس فومنتاريوس.

\begin{tabular}{|c|c|c|c|c|c|}
\hline P-value & F-value & مربع ميانَّين & درجه آزادى & مجموع مربعات & \\
\hline$\cdot / \cdot$ TDI & $9 / \Delta V$ & $1 \cdot / 4 T$ & f & $|4| / 99$ & مدل \\
\hline$\cdot / \cdot \wedge \notin \wedge$ & $\Delta / \Delta \Delta$ & $\Delta / \Delta \Delta$ & 1 & $\Delta / \Delta \Delta$ & $\mathrm{A}: \mathrm{MgSO}_{4} .7 \mathrm{H}_{2} \mathrm{O}(\mathrm{g} / \mathrm{L})$ \\
\hline$\cdot / r \wedge \cdots$ & . /QVYT & $1 / \cdot 9$ & 1 & $1 / \cdot 9$ & B:pH \\
\hline$\cdot / \cdot V T H$ & $\Delta / \Lambda \Lambda$ & $\varepsilon|4|$ & 1 & $g|4|$ & (g/L) عصاره مخمر (C \\
\hline \multirow[t]{3}{*}{$.1 .94 \wedge$} & tg/TF & TN/GV & 1 & TN/GV & (v/v): مايه تلقيح: \\
\hline & & $1 / \cdot 9$ & f & $\boldsymbol{r} / \mathrm{r \omega}$ & باقىمانده \\
\hline & & & $\wedge$ & $|\varepsilon| \cdot \Delta$ & مجموع \\
\hline
\end{tabular}

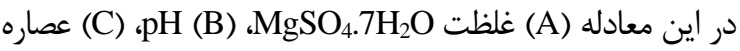

مخمر و (D) درصد مايه تلقيح است. نمودار دو بعدى و سلبعدى اثر داده

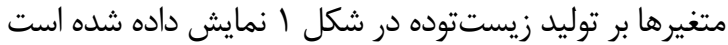

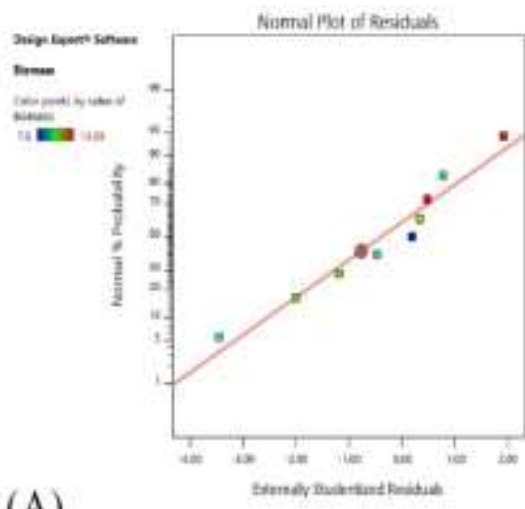

(A)

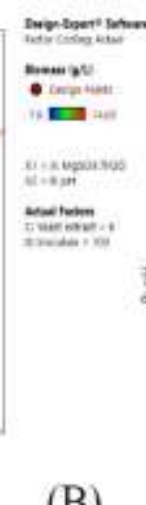

(B)
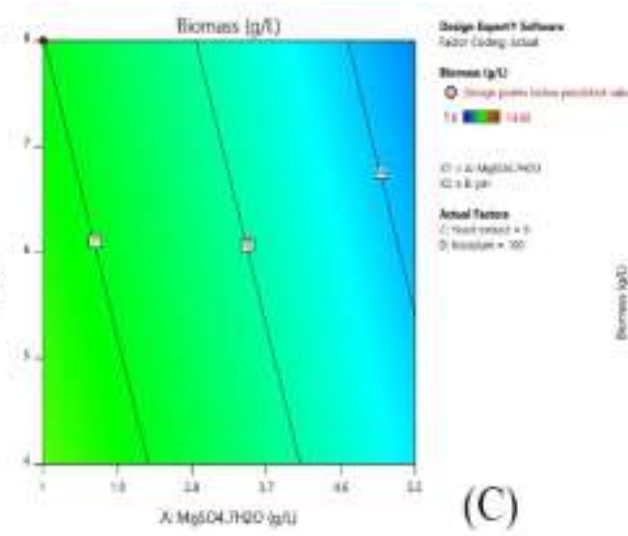

(C)

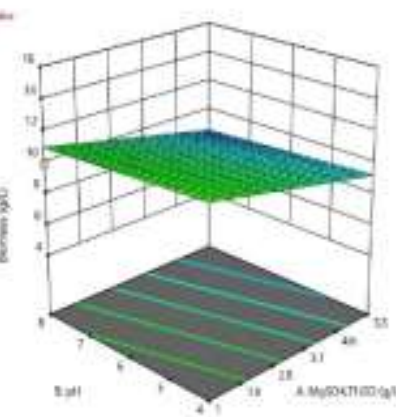

شكل ا. نمودار مقايسه ميزان زيست توده توليدشده و بِيشبينى شده (A)، نمودار دو بعدى (B) و سه بعدى (C) اثر متغيرهاى pH و أوليه بر توليد زيست توده قارج فومس فومنتاريوس. 


$$
\text { بر اساس هريك از متغيرها بهصورت زير است: }
$$

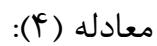

Polysaccharide: $3.71+1.45 \mathrm{~A}+0.8292 \mathrm{~B}+0.4427 \mathrm{C}-0.6025 \mathrm{D}$

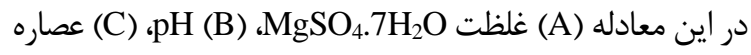
مخمر و (D) درصد مايه تلقيح است. نمودار دو بعدى و سلبعدى اثر مادل

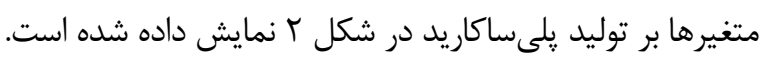

مقايسٔ ميزان ولى ساكاريد توليد شده در هر آزمايش و

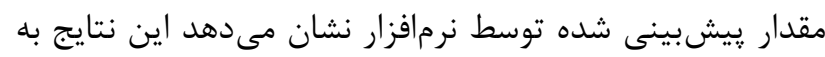

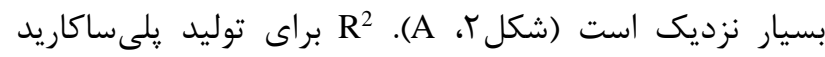

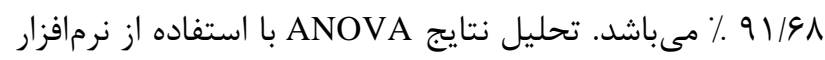

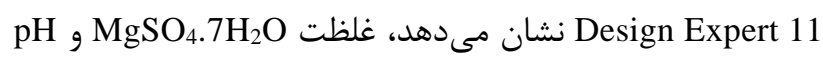

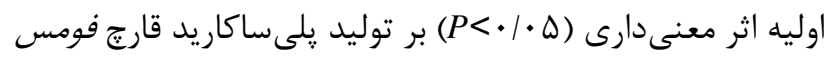

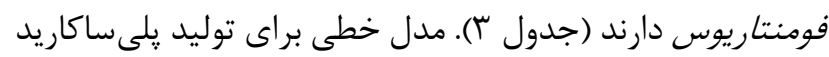

جدول با. آناليز واريانس و ضرايب ركرسيون براى توليد يلى ساكاريد قارج فومس فومنتاريوس.

\begin{tabular}{|c|c|c|c|c|c|}
\hline P-value & F-value & مربع ميانگين & درجه آزادى & مجموع مربعات & \\
\hline .1 .199 & $11 / \cdot r$ & $r / \Lambda)$ & f & $11 / T \Delta$ & مدل \\
\hline $.1 \cdot 90$ & TI/AF & $\Delta / \Delta \Lambda$ & 1 & $\Delta / \Delta \Lambda$ & $\mathrm{A}: \mathrm{MgSO}_{4 .} .7 \mathrm{H}_{2} \mathrm{O}(\mathrm{g} / \mathrm{L})$ \\
\hline.$/ \cdot 109$ & 19119 & $F / T$ & 1 & $F / \mu$ & B:pH \\
\hline . ITrAV & $r / \cdot \Delta$ & . /DTTY & 1 & . /DTTV & (g/L) عصاره مخمر (C) \\
\hline \multirow[t]{3}{*}{./llar } & $r / r$ & $1 / \cdot r$ & 1 & $1 / \cdot r$ & (v/v):D مايه تلقيح:D \\
\hline & & $\cdot / r \Delta \Delta{ }^{2}$ & i & $1 / \cdot r$ & باقىمانده \\
\hline & & & $\wedge$ & $I T / T V$ & مجموع \\
\hline
\end{tabular}
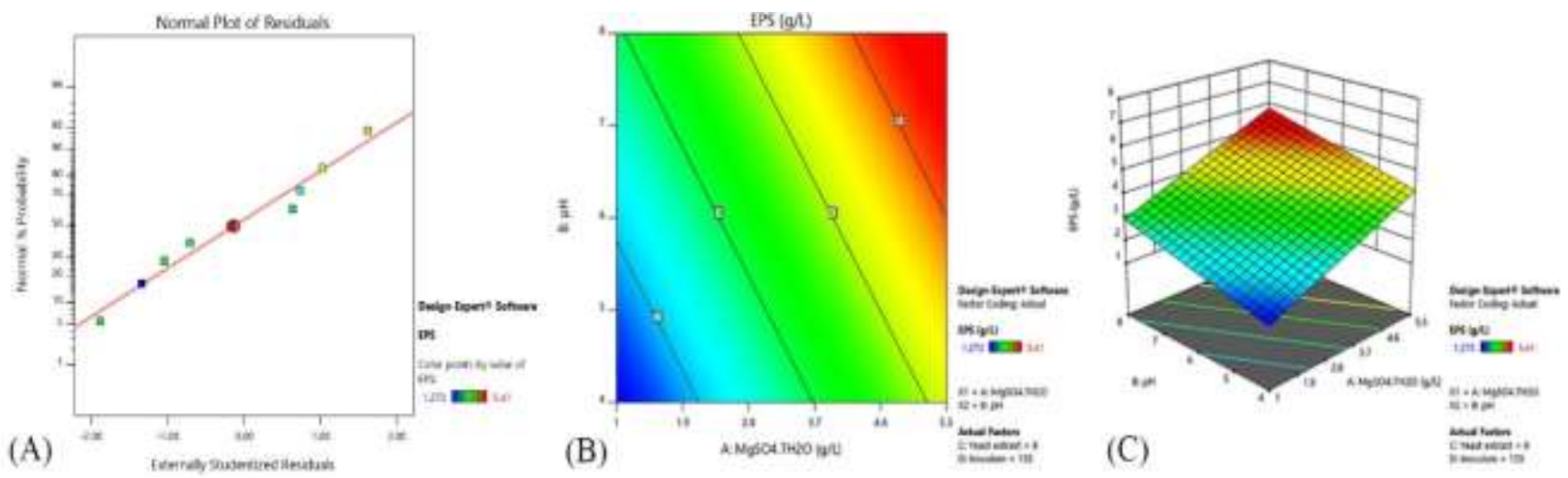

(C)

$+=$

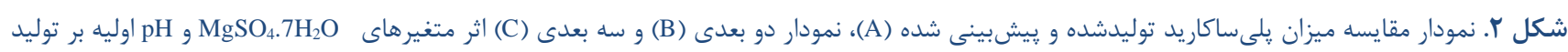
زيست توده قارج فومس فومنتاريوس.

بيشترين اثر مهارى را داشت (ه •|•>P). همرجنين اين نمونه بهينه

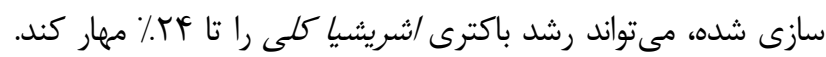

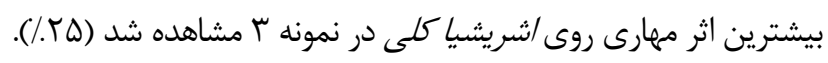

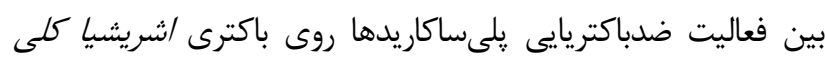

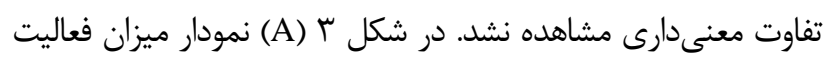

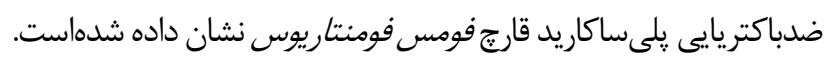

\section{فعاليت آنتى اكسيدانى}

فعاليت آنتىاكسيدانى يلىساكاريدهاى توليد شدهانى توسط

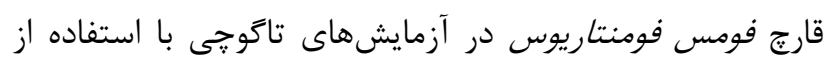
راديكال آزاد DPPH بررسى شد. زمانيكه ماده آنتىاكسيدان

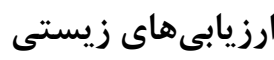

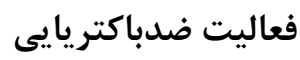

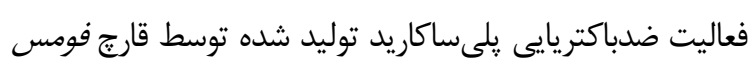

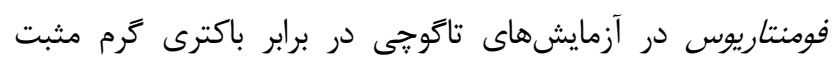

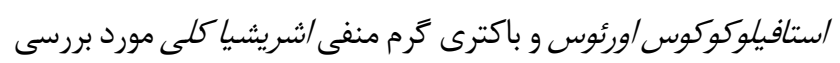

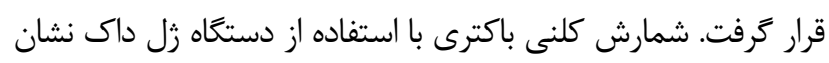

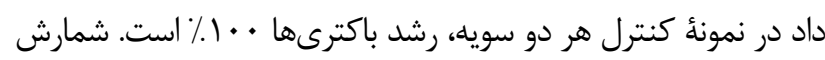

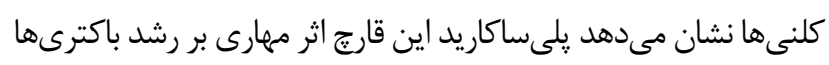

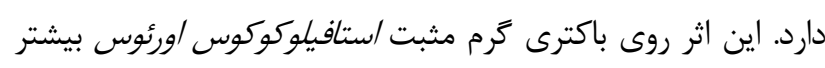

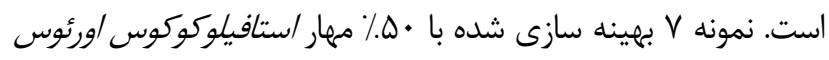


(شكل rا، B). تجزيه و تحليل نتايج DPPH نشان داد

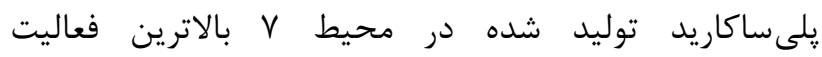

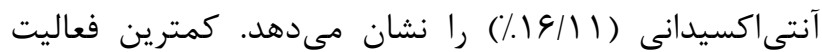

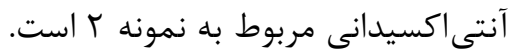

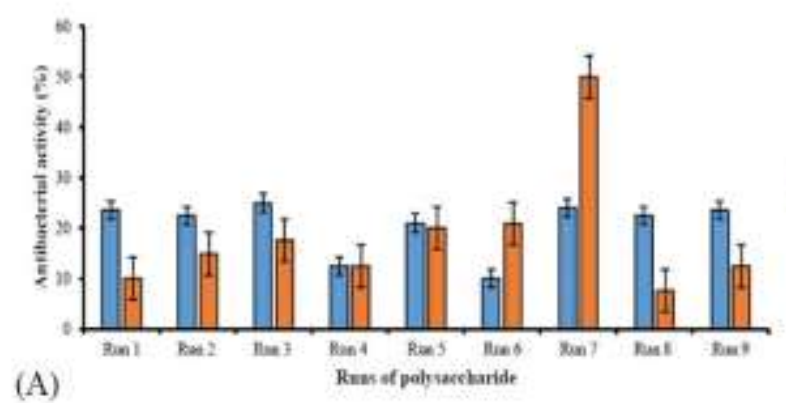

(A)

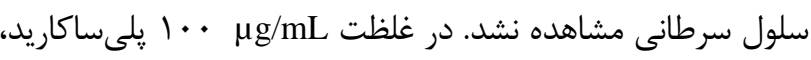
بيشترين اثر ضدتكثيرى روى رده سلولى AGS بوده و اين اثر به اله

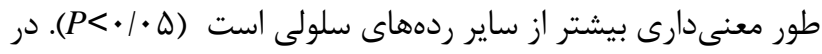

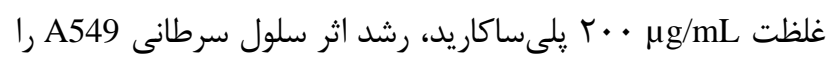

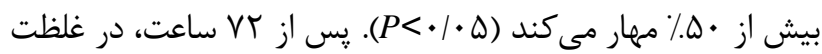

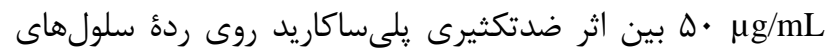

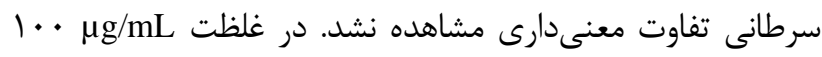

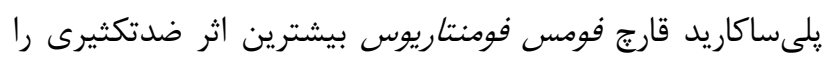

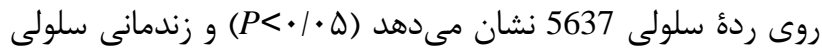

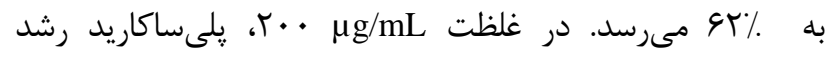

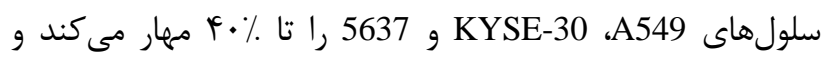
تفاوت معنىدارى در مقايسه با اين اثر روى سلولهاى MKN-45 و

$$
\text { AGS }
$$

يروتون در اختيار اين راديكال آزاد قرار مى دهد، جذب آن در

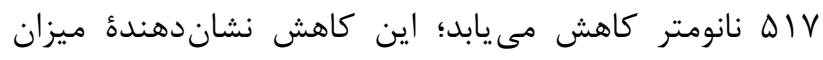

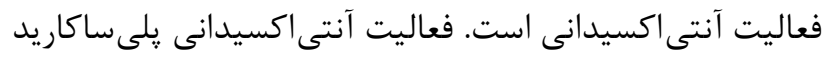

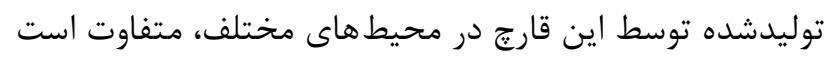

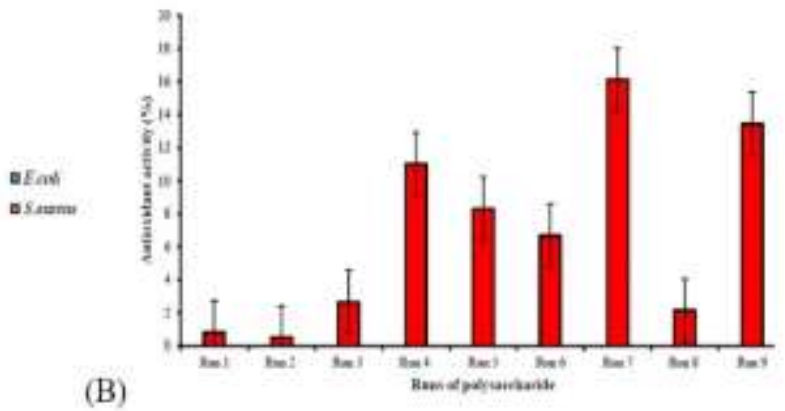

شكل r. فعاليت ضد باكتريايى (A) و آنتى اكسيدانى (B) بلى (A اكاريد بددستآمده از آرايه L9 تاكوجى.

بر رسى سميت سلولى

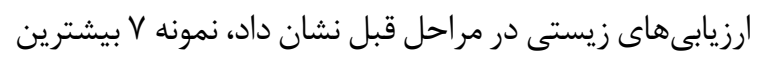

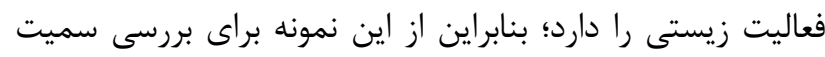

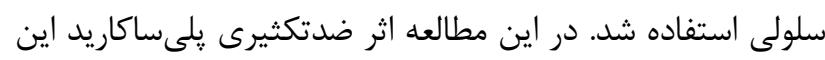

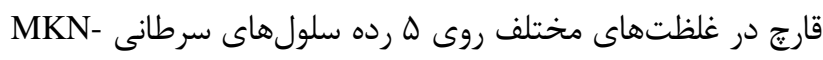

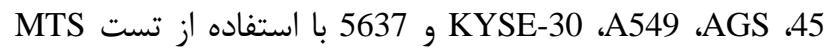
مورد بررسى قرار كرفت (شكل \&). بهطوركلى يلىساكاريد قارج

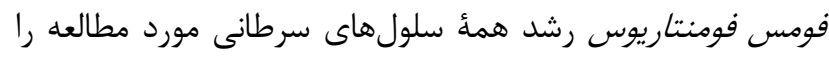

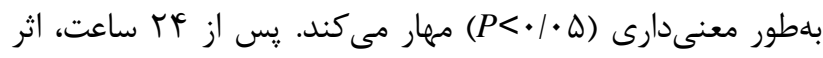

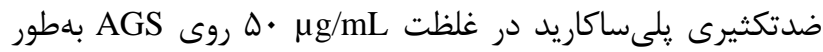

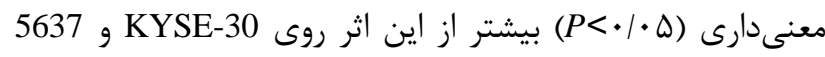

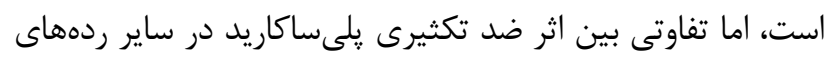

Ified of polysacthatide con cell lines $24 \mathrm{~h}$

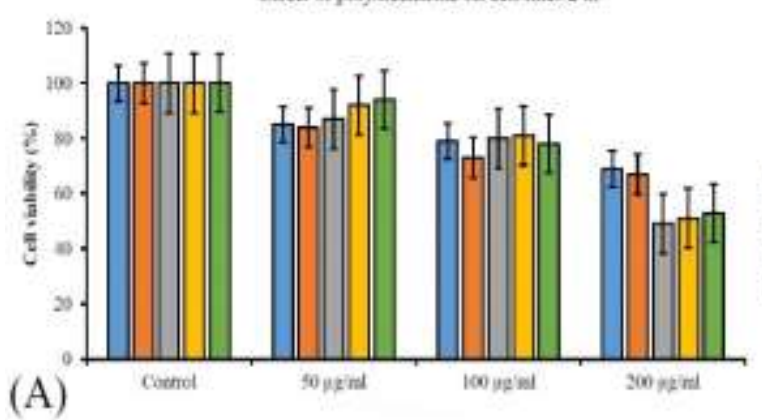

Effect of polysacchariste on cell lines (72h)

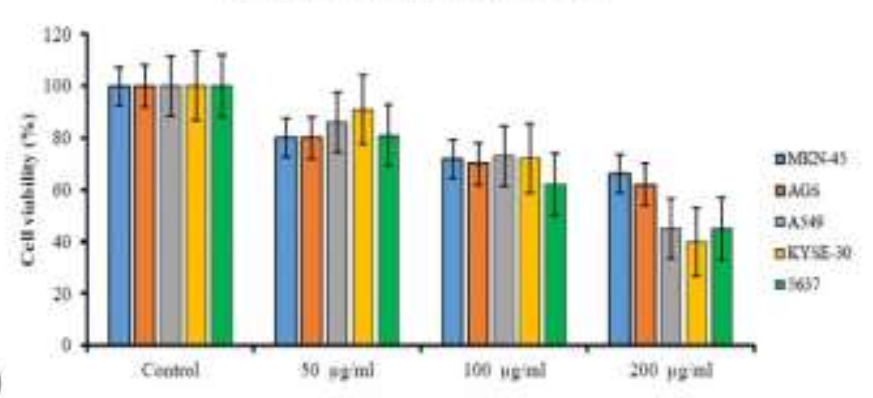

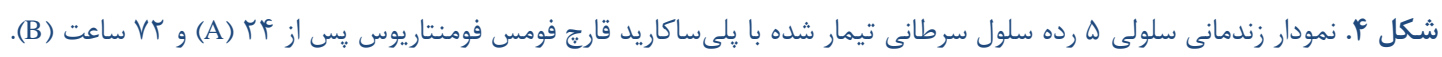




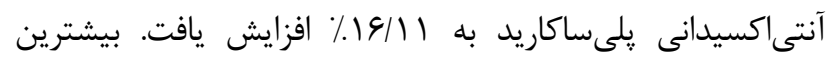

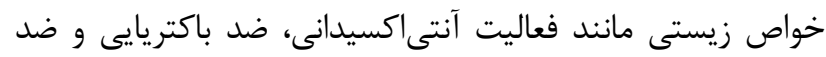
تكثيرى زمانى مشاهده مىشود كه pH اوليه محيط كشت قارج در

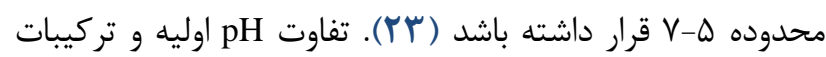
محيطكشت سبب تفاوت در محتواى فنولى يلى مساكاريد مىشوند. اين تركيبات با فعاليت آنتىاكسيدانى و كاهش راديكالهاى •OH' ور و $\mathrm{O}_{2}{ }^{*}$

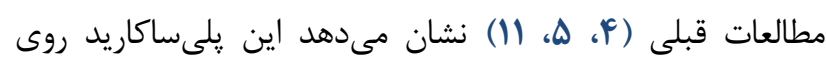
سلول هاى سرطانى اثر ضدتكثيرى دارد اما اين اثر در ردههاى سلولى دانى متفاوت بوده و با افزايش غلظت افزايش مىيابد. اثر ضدتكثيرى

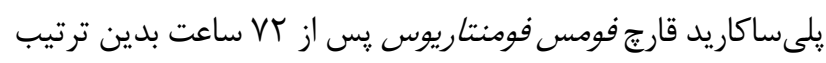

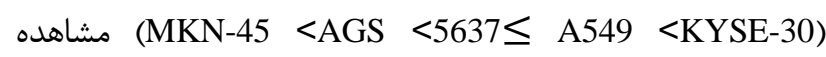
مىشود. در تيمار, سلولهاى

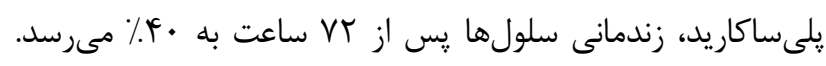

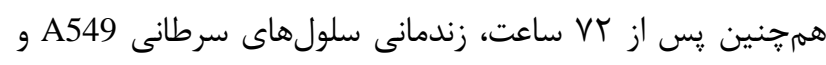

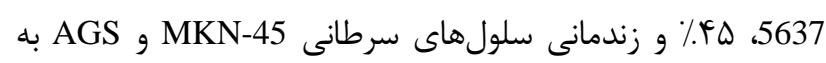

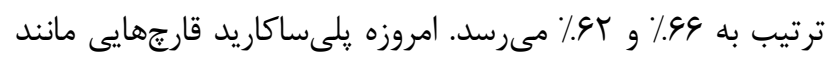

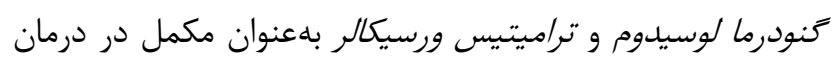

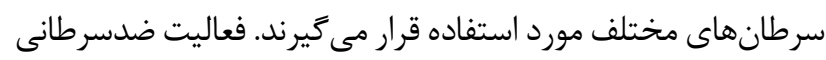
اين يلىساكاريدها شامل مهار رشد سلولهاى سرطانى و تقويت

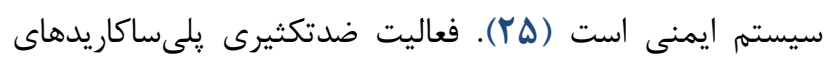
قارجى با ساختار شيميايى و تركيب مونوساكاريدهاى آنها در ارتباط است. يلىساكاريد قارج فومس فومنتاريوس غنى از بتاعلوكان است كه خواص ضد سرطانى دارد. اين تركيب سبب تخريب يروتئينهاى رونويسى در سلول سرطانى شده و زرخه سلولى را در مرحله متوقف مى كند. همرجنين با آسيب به اندامكها، هستهُ سلولى و قطعه

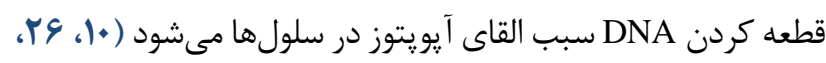
(YN rV rV

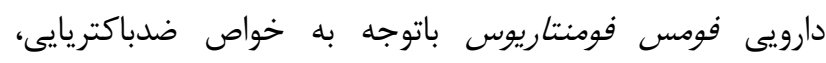

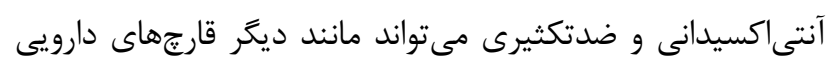
ززينهاى مناسب براى درمان بسيارى از بيمارىها بوده و بهعنوان مكمل غذايى مورد استفاده قرار زيرد.

\section{نتيجه}

در اين يزوهش توليد زيستتوده و يلىساكاريد قارج دارويى

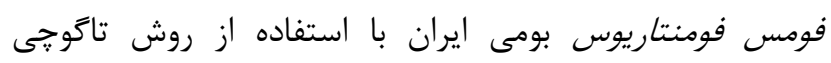

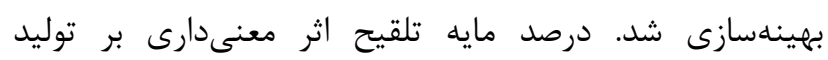

در اين مطالعه، بهينهسازى توليد زيستتوده و يلىساكاريد

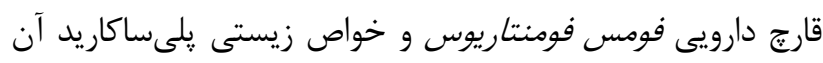
مورد بررسى قرار گرفت. همانطور كه در مطالعات قبلى (أ) و اين يزوهش مشاهده شد، محيط كشت مناسب اين قارج شامل كلوكز، يِّتون، عصاره مالت، عصارة مخمر،

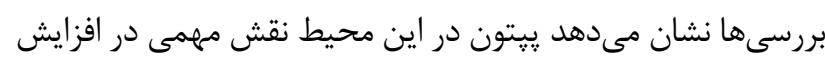

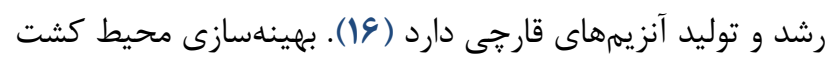
با استفاده از روش تاخوجى نشان داد غلظت اوليه تاثير معنىدارى (ه •|• دارند. با افزايش pH و اوليه توليد يلى إساراريد قارج

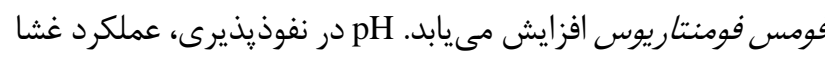
سلولى، و توليد متابوليتهاى ثانويه نقش دارد (II). منيزيمم عنصر مهمى در متابوليسم قارجها است. اين عنصر كوفاكتور بسيارى از واكنشهاى آنزيمى است و بر متابوليسم سلولى تأثير دارد. علاوه بر اين منيزيم سبب يايدارى غشاى سلولى و كاهش استرسهاى سلو سلى

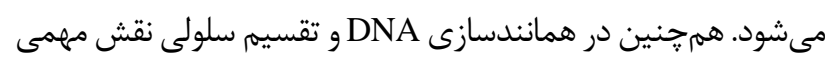

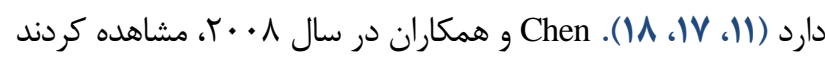
رشد قارج و توليد يلى ساكاريد آن با افزودن معنى دارى مىيابد. با بهينهسازى محيط يُشت، توليد يلى وساكاريد اين

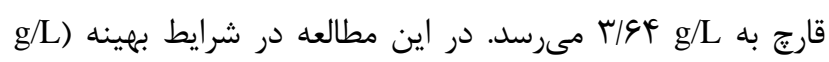

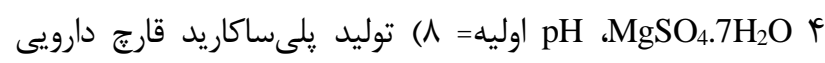

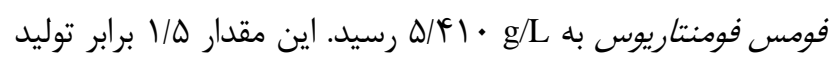

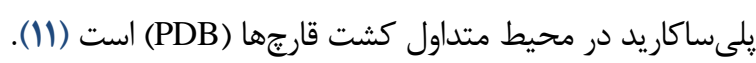
مطالعات نشان مىدهند شرايط فيزيكوشيميايى محيط كشت

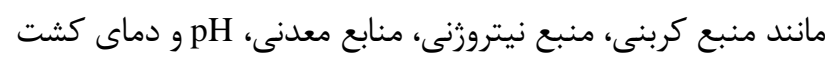
نقش مهمى در فعاليت زيستى متابوليتهاى قارجى دارند (19، • (؟).

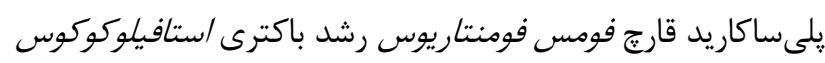

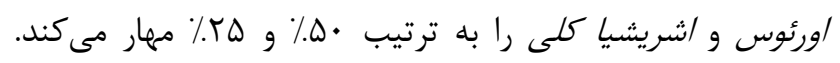
يلىساكاريد اين قارج حاوى ترينوئيدها و ويلىفنولها

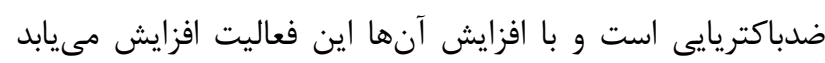
(Yl). مطالعات نشان مى مهد نوع و حجم حلال مورد استفاده براى استخراج يلى ساكاريدها در محتواى يلىفنولهان نقش دهان دارد. استفاده از حلالهاى قطبى مانند اتانول سبب افزايش يلى فينولها مىشود

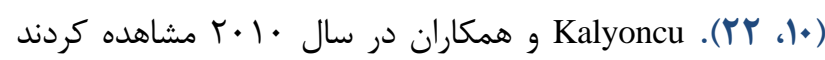

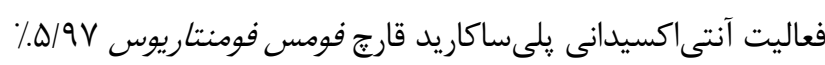
است. با بهينهسازى شرايط محيط كشت در اين زيزوهش، فعاليت 


$$
\text { سياسگزارى }
$$

اين مقاله بركرفته از پاياننامه كارشناسى ارشد با كد

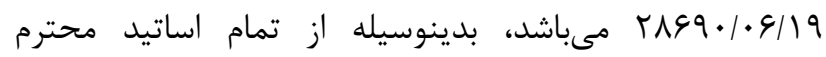

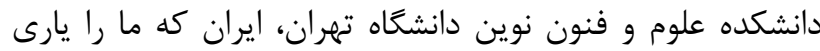
نمودند تشكر و قدردانى مى تردد.

$$
\text { تعارض در منافع }
$$

اين مقاله يزوهشى مستقل است كه بدون حمايت مالى

سازمانى انجام شده است. در انجام مطالعُ حاضر، نويسندًان هيج كونه تضاد منافعى نداشتهاند.

\section{Referance}

1. Cui J, Chisti Y. Polysaccharopeptides of Coriolus versicolor: physiological activity, uses, and production. Biotechnol. Adv. 2003; 21(2):109-122. [DOI:10.1016/S0734-9750(03)00002-8]

2. Asefshayan MR. Medicenal fungi of Iran, 247, Tehran: Iranshenasi; 2016.

3. Grienke U, Zöll M, Peintner U, M.Rollinger J. European medicinal polypores - A modern view on traditional uses. J. Ethnopharmacol. 2014; 154(3):564-583. [DOI:10.1016/j.jep.2014.04.030] [PMID]

4. Chen W, Zhao Z, Li YQ. Simultaneous increase of mycelial biomass and intracellular polysaccharide from Fomes fomentarius and its biological function of gastric cancer intervention. Carbohydr. Polym. 2011; 85(2):369375. [DOI:10.1016/j.carbpol.2011.02.035]

5. Kim SH, Jakhar R, Kang SH. Apoptotic properties of polysaccharide isolated from fruiting bodies of medicinal mushroom Fomes fomentarius in human lung carcinoma cell line. Saudi J Biol Sci. 2015; 22(4):484-490. [DOI:10.1016/j.sibs.2014.11.022] [PMID] [PMCID]

6. R-Hernandez L, CG-Franco A, S-Parra JM, MDominguez F. Review of agricultural and medicinal applications of basidiomycete mushrooms. Tecnociencia. 2008; 1(2):95-107.

7. Patel S, Goyal A. Recent developments in mushrooms as anti-cancer therapeutics: a review. 3 Biotech, 2012; 2(1):1-15. [DOI:10.1007/s13205-011-0036-2] [PMID] [PMCID]

8. Zang Y, Xiong J, Zhai WZ, Cao L, Zhang SP, Tang Y, Wanga J, Su JJ, Yang GX, Zhao Y, Fan H, Xia G, Wang CG, Hua JF. Fomentarols A-D, sterols from the polypore macrofungus Fomes fomentarius. Phytochemistry. 2013;

$$
\begin{aligned}
& \text { زيستتوده و غلظت pH و اوليه اثر معنى دارى } \\
& \text { بر توليد يلىساكاريد اين قارج دارد و در شرايط بهينه }
\end{aligned}
$$

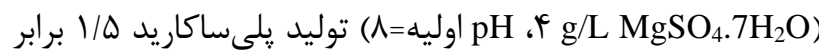

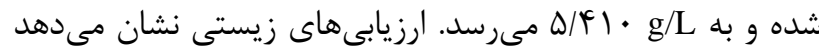

$$
\begin{aligned}
& \text { اين يلىساكاريد رشد باكترى /ستافيلوكوكوس /ورئوس و /شريشيا }
\end{aligned}
$$

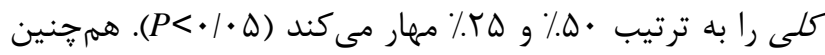

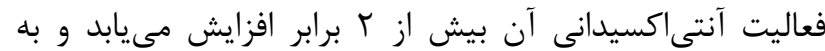

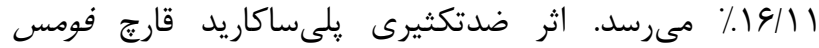

$$
\begin{aligned}
& \text { فومنتاريوس روى سلولهاى سرطانى متفاوت بوده و با افزايش }
\end{aligned}
$$

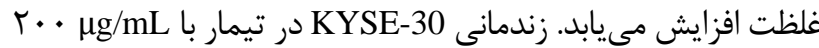

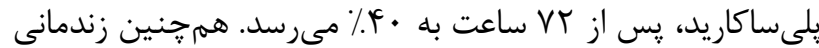

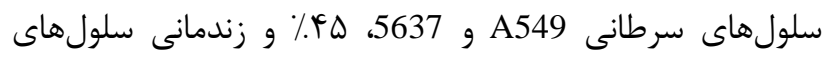

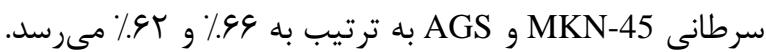

92:137-145. [DOI:10.1016/j.phytochem.2013.05.003] [PMID]

9. Krupodorova T, Rybalko S, Barshteyn V. Antiviral activity of Basidiomycete mycelia against influenza type A (serotype H1N1) and herpes simplex virus type 2 in cell culture. Virol Sin. 2014; 29(5):284-290. [DOI:10.1007/s12250-014-3486-y] [PMID]

10. Kolundzic M, Grozdanic ND, Dodevska M, Milenkovi'c M, Sisto F, Miani A, Farronato G, Kundakovi'ca T. Antibacterial and cytotoxic activities of wild mushroom Fomes fomentarius (L.) Fr.. Polyporaceae. Ind Crops Prod. 2016; 79:110-115. [DOI:10.1016/j.indcrop.2015.10.030]

11. Chen W, Zhao Z, Chen SF, Li YQ. Optimization for the production of exopolysaccharide from Fomes fomentarius in submerged culture and its antitumor effect in vitro. Bioresour. Technol. 2008; 99(8):3187-3194. [DOI:10.1016/j.biortech.2007.05.049] [PMID]

12. Neifar M, Jaouani A, Ayari A, Abid O, B-Salem H, Boudabous A, Najar T, E-Ghorbel R. Improving the nutritive value of Olive Cake by solid state cultivation of the medicinal mushroom Fomes fomentarius. Chemosphere. 2013; 91(1):110-114. [DOI:10.1016/j.chemosphere.2012.12.015] [PMID]

13. Houng JY, Hsu HF, Liu YH, Wu JY. Applying the Taguchi robust design to the optimization of the asymmetric reduction of ethyl4-chloro acetoacetate by bakers' yeast. J. Biotechnol. 2003; 100, 239-250. [DOI:10.1016/S0168-1656(02)00179-7]

14. Andreazza NL, De Lourenço CC, Stefanello MÉ, Atvars TD, Salvador MJ. Photodynamic antimicrobial effects of bis-indole alkaloid indigo from Indigofera truxillensis Kunth (Leguminosae). Lasers Med Sci. 2015; 
30(4):1315-1324. [DOI:10.1007/s10103-015-1735-4] [PMID]

15. Arab-Bafrani Z, Shahbazi-Gahrouei D, Abbasian M, Fesharaki M. Multiple MTS Assay as the Alternative Method to Determine Survival Fraction of the Irradiated HT-29 Colon Cancer Cells. J Med Signals Sens. 2016; 6(2): 112-116. [DOI:10.4103/2228-7477.181040] [PMID] [PMCID]

16. Qinnghe C, Xiaoyu Y, Tiangui N, Cheng J, Qiugang M. The screening of culture condition and properties of xylanase by white-rot fungus Pleurotus ostreatus. Process Biochem. 2004; 39(11): 1561-1566. [DOI:10.1016/S0032-9592(03)00290-5]

17. Okwudili U. Role of magnesium ions on yeast performance during very high gravity fermentation. J. Brew. Distilling. 2013; 4:19-45. [DOI:10.5897/JBD2013.0041]

18. M.R.Rees E, G.Stewart G. The effects of increased magnesium and calcium concentrations on yeast fermentation performance in high gravity worts. J. Inst. Brew. 1997; 103: 287-291. [DOI:10.1002/j.20500416.1997.tb00958.x]

19. Arora D S, Chandra P. Assay of antioxidant potential of two Aspergillus isolates by different methods under various physio-chemical conditions. Braz J Microbiol. 2010; 41(3), 765-777. [DOI:10.1590/S151783822010000300029] [PMID] [PMCID]

20. Bhattacharyya PN, Jha DK. Optimization of cultural conditions affecting growth and improved bioactive metabolite production by a subsurface Aspergillus strain tsf 146. Int J Appl Biol Pharm. 2011. 2(4): 133-143.

21. Prasad L, Kundu A, Bahukhandi D. Comparative analysis of volatile fractions of Fomes fomentarius and F.rhabarbarinus. Indian Phytopathol. 2018; 71: 25-31. [DOI:10.1007/s42360-018-0003-5]

22. Huang QL, Siua KC, Wanga WQ, Cheunga YC, Wu JY. Fractionation, characterization and antioxidant activity of exopolysaccharides from fermentation broth of a Cordyceps sinensis fungus. Process Biochem. 2013; 48(2):380-386. [DOI:10.1016/j.procbio.2013.01.001]

23. Kalyoncu F, Oskaya M, Kayalar H. Antioxidant activity of the mycelium of 21 wild mushroom species. Mycology. 2010; 1(3): 195-199. [DOI: $\underline{10.1080 / 21501203.2010 .511292}$

24. Miao L, F.N.Kwong T, Qian PY. Effect of culture conditions on mycelial growth, antibacterialactivity, and metabolite profiles of the marine-derived fungus Arthrinium c.f. saccharicola. Appl Microbiol Biotechnol. 2006; 72: 1063-1073. [DOI:10.1007/s00253-006-0376-8] [PMID]

25. R. Perron N, L. Brumaghim J. A review of the antioxidant mechanisms of polyphenol compounds related to iron binding. Cell Biochem Biophys. 2009; 53:75-100. [DOI:10.1007/s12013-009-9043-x] [PMID]
26. M.Zhang, S.W.Cui, P.C.K.Cheung, Q.Wang. Antitumor polysaccharides from mushrooms: a review on their isolation process, structural characteristics and antitumor activity. Trends Food Sci Tech. 2007; 18(1), 4-19. [DOI:10.1016/j.tifs.2006.07.013]

27. D-Petrova R, Z-Reznick A, P-Wasser S, M-Denchev C, Nevo E, Mahajna J. Fungal metabolites modulating NF$\kappa \mathrm{B}$ activity: An approach to cancer therapy and chemoprevention (Review). Oncology reports. 2008; 19(2):299-308. [DOI:10.3892/or.19.2.299] [PMID]

28. Queiroz EA, Fortes ZB, da Cunha MA, Barbosa AM, Khaper N, Dekker RF. Antiproliferative and proapoptotic effects of three fungal exocellular $\beta$-glucans in MCF-7 breast cancer cells is mediated by oxidative stress, AMP-activated protein kinase (AMPK) and the Forkhead transcription factor, FOXO3a. Int J Biochem Cell Biol. 2015; 67:14-24. [DOI:10.1016/j.biocel.2015.08.003] [PMID]

29. Choe JH, Yi YJ, Lee MS, Seo DW, Yun BS, Lee SM. 2015. Methyl 9-Oxo-(10E,12E)-octadecadienoate isolated from Fomes fomentarius attenuates lipopolysaccharide-induced inflammatory response by blocking phosphorylation of STAT3 in murine macrophages. Mycobiology. 2015; 43(3): 319-26. [DOI:10.5941/MYCO.2015.43.3.319] [PMID] [PMCID] 